\section{Who really acts as an entrepreneur in the science commercialisation process: the role of knowledge transfer intermediary organisations}

\author{
Aleksandra Szulczewska-Remi \\ Department of Controlling, Financial Analysis and Valuation, \\ Poznan University of Economics and Business, Poznań, Poland, and \\ Hanna Nowak-Mizgalska \\ Department of Microeconomics, \\ Poznań University of Economics and Business, Poznań, Poland
}

Who really

acts as an

entrepreneur

Received 10 September 2020 Revised 12 February 2021 6 April 2021 Accepted 9 May 2021

\begin{abstract}
Purpose - Consistent with the knowledge spillover theory of entrepreneurship, the purpose of this paper is to recognise the complementary entrepreneurial role of knowledge transfer intermediary organisations in the context of two Central and Eastern European (CEE) countries: Poland and the Czech Republic.

Design/methodology/approach - The aim was achieved through empirical studies relying on multiplecase study methodology and cross-case analysis covering 21 cases of commercialisation intermediary institutions. It was assumed that institutional and geographical conditions can impact the knowledge-based opportunity exploitation between different national economies.
\end{abstract}

Findings - Research confirmed that scientists in Poland and the Czech Republic are the central figures of the commercialisation process in terms of entrepreneurial opportunity recognition; however, they need support from intermediary organisations in many other entrepreneurial activities. The history of knowledge commercialisation and its intermediating entities in these countries is relatively young and spin-off company creation is not a common practice. Expertise knowledge, creativity and self-confidence admitted, by the respondents in both countries, can be an optimistic sign for the future efforts in fostering innovativeness of CEE countries. Stronger support of formal institutional framework and policies in those countries is expected.

Originality/value - Science commercialisation has lately attracted much attention, but only a few studies have tried to develop conceptual frameworks considering knowledge-based entrepreneurship and knowledge commercialisation in their relations and subsequential roles. Also, over the past couple of years literature in this area has expanded mainly relying on observations in the USA and Western European countries. Hence, this study allowed to collect findings from CEE countries for which data are still insufficient but can

(C) Aleksandra Szulczewska-Remi and Hanna Nowak-Mizgalska. Published by Emerald Publishing Limited. This article is published under the Creative Commons Attribution (CC BY 4.0) licence. Anyone may reproduce, distribute, translate and create derivative works of this article (for both commercial and non-commercial purposes), subject to full attribution to the original publication and authors. The full terms of this licence may be seen at http://creativecommons.org/licences/by/4.0/ legalcode

The project financed within the Regional Initiative for Excellence programme of the Minister of Science and Higher Education of Poland, years 2019-2022, grant no. 004/RD/2018/19, financing 3,000,000 PLN.

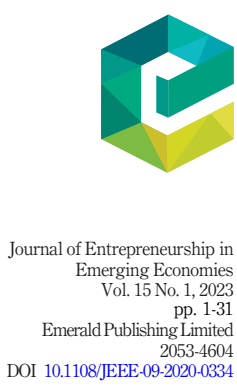


JEEE

15,1

significantly contribute to the theory development. Also, some recommendations for policymakers arise from this study. Further research could validate the results in an extensive quantitative study.

Keywords Commercialisation, Technology transfer, Entrepreneurial university, Intermediary organisations, Knowledge-based entrepreneurship

Paper type Research paper

\section{Introduction}

There has been a growing interest in international studies concerning research productivity and the effects of scientists' work through the commercialisation process (Moutinho et al., 2016; Reyes, 2016; Hayter et al., 2018; Suhaimi et al., 2020). Research commercialisation through the intellectual property creation, knowledge transfer and new venture formation is closely related to both knowledge-based entrepreneurship (KBE) and academic entrepreneurship, which are both related to the phenomenon of entrepreneurship. KBE is defined as the ability to recognise opportunities or the commercial potential of the invention that create value through the use of innovation (Hayter, 2013). It is directly related to entrepreneurial endeavours by academic researchers (Moutinho et al., 2016) and is measured by the number of new single-unit establishments in industries (Qian, 2017) like high-technology start-ups, corporate spin-offs and university spin-offs (Hayter, 2013). KBE is similar to the concept of academic entrepreneurship; however, academic entrepreneurship in addition to spin-off formation covers other differing activities like obtaining externally funded research projects, contacted research with external organisations, consulting, patenting, licensing, external teaching or commercial selling of products (Klofsten and Jones-Evans, 2000).

Although science commercialisation is seen as an entrepreneurial process (Witt and Zellner, 2005), more complex studies regarding entrepreneurial resources, capabilities and activities needed in the whole process of knowledge transfer into the market are rather scarce. In general, research concentrates on internal factors, such as scientists' intentions or motivations to commercialise their research results (Miranda et al., 2017; Nguyen et al., 2018; Neves and Brito, 2020 ) or on the complementary role of intermediary organisations, which support academics in the commercialisation process (O'Gorman et al., 2008; Clayton et al., 2018). Such intermediaries are generally seen as operating "behind the scenes" and their effectiveness is not fully recognised (Clayton et al., 2018) while their activities can be, in many cases, crucial for the success of science commercialisation, and they should exactly respond to the deficiencies in entrepreneurial capabilities of individual scientists or scientific teams. According to Suvinen et al. (2010), the functionality of intermediaries is conditioned by a regional and sectorial context, as well as by support for a university-industry relationship. Intermediaries can even act as institutional entrepreneurs (Poppen and Decker, 2018), so it is not so obvious, who realise subsequent entrepreneurial functions in the commercialisation process.

Building on the concept of knowledge spillover theory of entrepreneurship (KSTE), we refer to the approach described by Audretch and Keilbach (2007) in which entrepreneurship serves as a conduit of knowledge spillover in the research commercialisation process. In other words, more knowledge will generate more entrepreneurial opportunities. However, new knowledge does not spill over automatically, that is why some kind of entrepreneurial activities are needed to transfer knowledge into economically useful concepts (Hayter, 2013).

Also, research commercialisation is seen as a key process by which investments in publicly funded research generate impacts on society and the economy (Pisano, 2006; Ting et al., 2019). Because knowledge commercialisation is the driving force of innovation for many companies and also an important part of the innovation process' management, there is still a great potential in more focused and conceptually driven research in the area (Fini et al., 2018). 
According to Kotlar et al. (2018), only few studies have used empirical data from science commercialisation context and because of its multidimensional nature there is still a void in our theoretical understanding of the process. Also, Perkmann et al. (2013) argue that the state of knowledge about commercialisation remains relatively fragmented. Moreover, there is no unique model of knowledge transfer into its commercial applications, because of different institutional and cultural environments in studied countries (Maresova et al., 2019) both, at the level of organisation (entrepreneurial university) or at the regional/national level (entrepreneurship culture). These conditions can affect significantly different results of science commercialisation in different regions (e.g. the number of spin-offs), according to geographical location or institutional background (Fritsch et al., 2019; Stuetzer et al., 2018). So far, not all institutional environments were studied with the same intensity. Thus, research from Central and Eastern European (CEE) countries can add to our knowledge substantially. Cunningham et al. (2017) emphasise that more studies from this region are needed for further contribution to the field, providing insights into different contextual approaches and practices.

Applying this, we introduced a cross-case analysis based on commercialisation intermediary institutions, to investigate their role in supporting commercialisation seen as an entrepreneurial process. We also refer to previous work by Clayton et al. (2018), who described intermediaries as institutions that "diffuse knowledge across firms and supply chains" or more precisely "entities that operate in the void between the scientific discovery and the ultimate realization of value from commercialisation, providing specialized services and access to equipment and resources" and ask for a better understanding how these organisations contribute to the concept of knowledge spillovers. Therefore, the main objective of this paper is to recognise the complementary entrepreneurial role of knowledge transfer intermediary organisations in the context of two CEE countries: Poland and the Czech Republic. These two countries have similar historical and cultural backgrounds, and both are recently considered as moderate innovators, when we take into consideration the level of innovativeness of the national economies. However, the institutional (e.g. legal) ecosystems for supporting science commercialisation are not fully established yet, and the entrepreneurial capabilities of potential academic entrepreneurs need to be constantly developed to foster KBE in those countries (Brooks et al., 2019). Thus, they represent an interesting example for studying the relationship between scientists and knowledge transfer intermediary organisations' functions in an entrepreneurial process of research commercialisation.

The paper is organised as follows: the paper begins with an introduction, followed by a review of the theoretical $\mathrm{KBE}$ and commercialisation background. The methodology is presented in Section 3, and Section 5 reflects on the findings of the study in the context of future recommendations and policy development.

\section{Theoretical background}

\subsection{Knowledge transfer and commercialisation as an entrepreneurial process}

Entrepreneurship as a socio-economic phenomenon has been studied through the lenses of different theoretical and methodological perspectives, assuming different levels of analysis (Low and MacMillan, 1988). Shane and Venkataraman (2000) defined three important conditions for the appearance of entrepreneurship: the existence of entrepreneurial opportunities, their discovery and the decision to exploit them. Referring to the knowledge transfer and commercialisation it seems to be interesting but ignored in most studies that recognition of entrepreneurial opportunities may be to some point shared between scientists and intermediary organisations, which intervene in the process.

Krueger (2000) claimed that the opportunities are the object of creation which is supported by the critical factors related to the perceptions and cognitive structures of individuals. Alvarez and Busenitz (2003) included the cognitive capacity of individual 
JEEE

15,1

entrepreneurs into the resources-based theory, referring to the opportunity recognition and the process of combining and organising resources. Because commercialisation transforms from a technology-driven process into a market-driven process (Spilling, 2004), it may occur via academic entrepreneurship, that is the founding of a firm with the objective to commercially exploit a patented invention, or in some cases, a body of unpatented expertise (Shane, 2004). While scientists are actors who create new knowledge, sometimes they may lack cognitive capacity for recognising entrepreneurial opportunities and transforming it into economically useful knowledge, so they need support from other entities through education (Linton and Xu, 2021). According to Audretsch and Kayalar-Erdem (2005), there is a void in our understanding how universities and public policies impact cognitive processes of scientists in both recognising entrepreneurial opportunities and taking the decision to become an entrepreneur. This is why the role of intermediary organisations like technology transfer centres, in this context should be explored.

The mechanism that allows to change scientific knowledge into economically useful knowledge requires entrepreneurial resources (e.g. scientifically trained personnel) and activities, however, scientists can act as entrepreneurs starting and running their own knowledge-based ventures, or they may be employed in other enterprises that exploit knowledge-based entrepreneurial opportunities (Witt and Zellner, 2005). Also, the character of knowledge (tacit or encoded) is of great importance in this process. The commercialisation of tacit knowledge without the participation of the scientist is practically impossible, while encoded knowledge can be reproduced by other members of the entrepreneurial team (Witt and Zellner, 2005).

We agree that in the commercialisation process the entrepreneurial competences are needed, but, according to the adopted form of the commercialisation effects (e.g. spin-off venture creation or licensing) the scientist who participated in the research project can be personally involved and act as an entrepreneur or not. It depends on many factors related to his or her entrepreneurial intentions, motivations, attitudes and ability to recognise opportunities. This group of factors relates to the individual characteristics of academic entrepreneurs, such as creativity, risk propensity or self-confidence. For example, Miranda et al. (2017) have studied the determinants of academics' entrepreneurial intentions in Spanish universities. According to the results of their study, the entrepreneurial intentions of academics in this country were explained by entrepreneurial attitudes influenced by creativity and perceived utility regarding income, work effort and risk involved in the process.

According to Audretch and Keilbach (2007), entrepreneurial opportunities should not be taken for granted, because they are rather created by investments in knowledge and ideas generated by incumbent organisations (e.g. firms or universities). In their KSTE, the attention is given to the different external conditions for entrepreneurship. It means that more knowledge existing in a given context will generate more entrepreneurial opportunities, and entrepreneurship or entrepreneurial activity serves as a "conduit facilitating the spillover and commercialisation of that knowledge" (Acs et al., 2009; Audretch and Keilbach, 2007, p. 1246). In line with this theory, in different countries and institutional contexts, different conditions for knowledge-based entrepreneurial opportunities exist.

Davey et al. (2016) have investigated the influence of context on academic entrepreneurship in different European countries. According to these authors, specific institutional conditions at the national level affect the perception of the drivers and barriers for academic entrepreneurship. The results confirmed the lowest extent of academic entrepreneurship in the Eastern Europe region (with selected countries: Poland, Hungary and Romania) as compared to other studied regions. Moreover, this region was marked by the highest barriers and the lowest drivers of the university-business collaboration. In all studied regions, cultural and funding barriers for academic entrepreneurship were identified (Davey et al., 2016). In relation to the 
barriers of academic entrepreneurship in Poland, Brendzel-Skowera (2016) points out that the internal conditions of the universities' functioning are responsible for this situation. In contrast, for example, in Italy, the impact of context at the university level for the innovative performance of university spin-offs was confirmed, especially in case of universities with business incubators and science parks (Corsi and Prencipe, 2016).

Hayter (2013) stressed the importance of entrepreneurship networks as the source of knowledge, information and resources. In the process of research, commercialisation networks can help reduce the deficiency in different aspects of KBE of the potential academic entrepreneurs. Considering the above mentioned internal and external factors that shape the ability of academic community to commercialise their inventions through the entrepreneurial behavior and drawing on the above literature, we developed our conceptual framework of the research as presented in Figure 1.

KBE and related academic entrepreneurship is seen in the literature as the vehicle which helps transfer scientific knowledge into commercial applications, and for that, to improve the level of competitiveness and innovativeness of the economy and social prosperity. In the research and development (R\&D) results, commercialisation process and entrepreneurial activities are needed to identify entrepreneurial opportunities or to organise resources. Entrepreneurial capacity of academic community members has to be strengthened by institutional environment, both formal and informal. Especially in CEE countries, which experimented the transition from centrally planned into a free market-based economy, which was also related to a lack of trust in business and social environment (Brooks et al., 2019).

\subsection{Research commercialisation in the context of transition economies}

The second part of the theoretical background explores the research commercialisation process in the institutional context of transition economies, with a special emphasis on the role of intermediary organisations (e.g. academic entrepreneurship incubators or technology transfer centres). Assuming the importance of $\mathrm{KBE}$ in research commercialisation, intermediary organisations can help develop or improve some part of entrepreneurial capabilities of academic

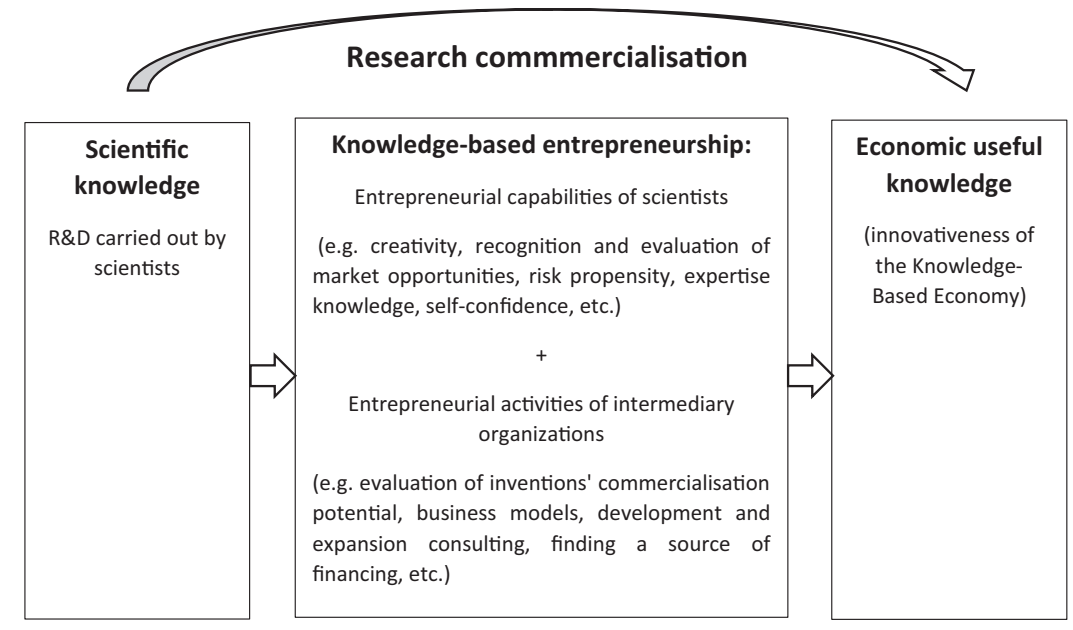

Source: Own elaboration

\section{Who really \\ acts as an \\ entrepreneur}

Figure 1.

Conceptual

framework of research

commercialisation as an entrepreneurial process 
JEEE 15,1

community members, and in some cases, they may even try to supplement insufficient entrepreneurial competency (e.g. ability to organise external resources), depending on the forms and expected effects in the research commercialisation process (O'Gorman et al., 2008).

Commercialisation of research results is a multidimensional process that enables the innovator (the creator of innovation) to achieve economic benefits from the implementation of scientific research results into business practice. In-depth recognition of the inventions' advantages and assessment of its market potential are indispensable elements of the process (Fini et al., 2018). Therefore, commercialisation enables the flow of innovation from the basic research to commercial entities and then to public use (Van Norman and Eisenkot, 2017). Based on the European Union (EU) definition, commercialisation brings intellectual property to the market for generating future profits and business growth, turning products or services into commercially noticeable value (European Union, 2016). In this process, universities are seen as an effective vehicle for knowledge and technology transfer providing intellectual property, licensing, patenting, franchising, spin-off and spin-out companies.

In the literature data there are number of different commercialisation paths like:

- selling the outcome of research;

- grant licensing of R\&D outcomes; and

- making research contributions to the firms.

The process of commercialisation was wildly described by scholars as a stage model process which may vary between a very simple to a more sophisticated approach (Bercovitz and Feldmann, 2006; Jolly, 1997; Kozmetzky et al., 2004; Virttanen and Laukanen, 2002). It starts out with idea generation through the incubation process, new venture creation and possible established business activity. Klincewicz (2011) sees it as the process of implementing and offering an innovative product (technology) to customers. Kluczek (2011) highlights that commercialisation is the whole activity aimed at transferring knowledge from the laboratory to the market. Commercialisation of research involves activities aimed at developing a business model, designing the process of selling technologies on market, ensuring that a potentially valuable invention creates technology-based added value.

A large pool of publications defined two main ways of commercialisation, i.e. direct commercialisation through direct sell of research results with contracted receipt of royalties (Bradley et al., 2013; Jensen and Thursby, 2001; Powers and McDougall, 2005; Wnuk and Tommei, 2015) or indirect commercialisation (creating a company that was founded by inventors coming from the same scientific institution in a form of spin-off, spin-out or startup or by gaining a license for the developed solution) (Shane, 2004; Szulczewska-Remi, 2016). Thus, studies that explain commercialisation of university research refer to KSTE as Acs et al. (2013) point out: "By commercialising the ideas that evolved from an incumbent organisation but commercialised independent of this organisation via the creation of a new firm, the entrepreneurs not only serve as a conduit for the spillover of knowledge but also for the ensuing innovative activity and enhanced economic performance." Furthermore, in the context of KSTE, the authors described a number of factors that influence differences between regions and countries in fostering the process of knowledge transfer. One of the most important one is the role of stakeholders that intermediate in commercialisation like special purpose vehicles (SPVs) or special purpose entities (SPEs), entrepreneurship centres, science and technology parks, technoparks, academic incubators, technology transfer offices or centres (TTO) (Kolympiris and Klein, 2017; O'Kane et al., 2015; Siegel et al., 2007; Wright et al., 2008;) described lately by Kher and Lyons (2020) as university-based venture development organisations (VDOs). Based on research by Belitski et al. (2019), we assume 
the theoretical framework for these studies builds on the university organisational structures that support the commercialisation perspective of the KSTE where only their organisational level with the individual perspective of KSTE and university perspective is taken into account.

Applying this, the role of administrative units within universities that support commercialisation is to identify targeted market and implementation, providing research infrastructure, building relations with industry, generating royalties and funding support for university research and stimulate new venture creations like spin-offs (Clarysse et al., 2011b; Wright et al., 2009). Fitzgerald and Cunningham (2016) based on Irish universities research suggest that TTOs' missions are to manage the university created discoveries, exploit created intellectual property and to promote regional growth economic development and job creation through, e.g. start-up initiatives. Intermediaries are therefore especially important for science-based entrepreneurial companies to overcome information and resource asymmetries and to help young innovative entrepreneurs to refine their ideas and business plans, reducing the transaction costs arising during commercialisation. It has also been studied that VDOs play an essential role in coordinating networks between the sciencebased community and industry (Clayton et al., 2018). Previous work by Capat and Sandelin (2004) also suggested TTO roles in recruiting faculty and graduate students. This however refers more to the whole of activities related to sharing the results of scientific research, the term often used in the context of a wide and universal transfer of research results. Though, van Norman and Eisenkot (2017) emphasise that research commercialisation covers all of activities related strictly to the provision of access to research results to third parties or the transfer of results to such entities.

In developed countries, commercialisation intermediating organisations model involvement is well described (Siegel et al., 2003) starting with scientific discovery followed by the invention disclosure signed by the authors with the TTO or other university settings. At this point, the decision about intellectual property rights is made, e.g. whether to patent the invention. The next stage usually involves market research identifying possibilities for licencing or selling followed by seeking an investor or entrepreneur. In the last stage, an invention is finally converted into a commercialised product with or without university engagement, e.g. in the case of spin-off or spin-out venture faculty members can act as active board members or scientific consultants. Several successful examples have been implemented like the 3GU model at the University of Oxford, the Office of Technology Licencing of Stanford University or the Office of Intellectual Property and Industry Research Alliances at UC Berkeley. However, Dvouletý et al. (2018) point out that effective solutions from established economies cannot be taken for granted as they depend on the quality of organisations in economies. Malerba et al. (2016), who examined the growth of knowledge-intensive entrepreneurship in China, India, and Russia, noticed that a series of policies in these countries have been launched to provide a favourable entrepreneurial environment like several science and technology parks in China that attract returnees from Western countries to use their knowledge. In Russia, the main emphasis is placed on earlystage development, high-tech companies; the main hurdle is that innovative enterprises never mature to world-class players. According to Belitski et al. (2019), universities in transition countries do not have the same organisational flexibility and a well-defined academic entrepreneurial culture.

To identify wider technology and knowledge, intermediary functions in Eastern European countries, we use examples of Poland and the Czech Republic (Czechia). Both countries experienced economic transformation into ones of the most robust in Central Europe with gross domestic product (GDP) US\$586m for Poland and US\$244,1m for 
JEEE

15,1

Czechia. In terms of GDP per capita US\$15k versus US\$22.9k, respectively. Also, both countries are classified as moderate innovators according to the European Innovation Scoreboard (2019), however for the performance between 2011 and 2018 Poland improved by $7.8 \%$, especially after 2015 , while the Czech Republic, $3.5 \%$. Poland was classified above the EU average in the innovation-friendly category and improved by $155.7 \%$ (highest growth in the EU) during the same period of time. Similarly, total entrepreneurial activity of Poland $(8.3 \%)$ was above the EU average $(6.7 \%)$ (European Innovation Scoreboard, European Commission, 2019). Surprisingly, innovators, which was one of the most important innovation dimensions for the Czech Republic, was Poland's weakest dimension. Stemberkova et al. (2016) noticed, while comparing the relative number of patent applications, the largest increase for Poland and Czechia compared with 2005 and 2011. Special attention should be given to the motivational index which has improved recently for those two countries. In the case of Poland, opportunity-driven entrepreneurship has even overpassed the necessity-driven entrepreneurship. Poland also has a high share of the population who completed tertiary education. On the other hand, Poland has less attractive research systems and worse indicators of innovators in the population of SMEs, firm investments and public and business R\&D expenditure than does the Czech Republic (European Commission, 2019).

In the past couple of years, Polish and Czech scientists and entrepreneurs have begun to recognise the necessity of translating research results into market-valuable innovations. However, the history of knowledge commercialisation and its intermediating entities in these countries is relatively young. In Poland in 2014, the Ministry of Higher Education amended the Higher Education Act that has given universities a great deal of leeway in developing their own commercialisation systems. In the Czech Republic, the Technology Agency of the Czech Republic (TACR), main governmental body on the support of research and innovation, only in 2013 and 2014 initiated a series of studies to identify the current major barriers that limit effective commercialisation. Based on their findings, TTOs are not well anchored within research organisations and their actions are not fully underutilised (TACR, 2014). Moreover, Andera and Lukeš (2016) noticed that in Czechia there is no public register of entrepreneurship supporting institutions like business incubators.

Similarly, consistent with the "Polish Applied Sciences" report (PAP Foundation, 2018) academic institutions in Poland do not sufficiently support scientists who commercialise their research and there is a general lack of trust between science and business, subsequently leading to the lack of R\&D financing from large domestic corporations rather than governmental funds. Munari et al. (2016) found out that in Poland and in the Czech Republic university-industry technology transfer is mainly founded by a central ministry or by a national innovation agency rather than a regional innovation agency typical for countries with prolonged practice in technology transfer and more developed commercialisation systems. One of the major problems in Czechia is also associated with low effectiveness of TTOs caused by low qualifications of technology transfer professionals (Dvorák and Ciharová, 2013). As confirmed by Munari et al. (2018) in Eastern European countries TTOs are much smaller (approximately nine people) and experience relatively lower assessment by TTO managers.

Overall, entrepreneurship plays an important role in both countries' regional economic development and there is still a need for supporting a growing national innovation ecosystem (Andera and Lukeš, 2016; Dvouletý, 2017; Trzmielak, 2013). In the Polish "Strategy for Responsible Development" it is expected to increase research spending to approximately 3\% of GDP and create 1.5 thousand new start-ups by 2023 (Ministry of Infrastructure and Development, 2017). For comparison, in the Czech Republic the share of 
total R\&D and innovation expenditure is projected to $2.0 \%$ of GDP in 2020 and $3.0 \%$ in 2030 according to "Innovation Strategy of the Czech Republic 2019-2030" (Council for Research, Development and Innovation, 2019). The main obstacles of support of essential knowledgebased entrepreneurial services provided by technology transfer intermediary organisations remain. It is essential that all these entities are given access to everything needed to increase and improve efficiency, because the competitiveness of regions tend to increase based on their capacity for managing and valorising knowledge (Schiuma and Lerro, 2010; Secundo et al., 2017).

\section{Research methodology}

To conceptualise KBE and knowledge commercialisation, an extensive literature study was performed. Based on a literature search in leading management and commercialisation journals, we identified articles that used empirical data from science entrepreneurship and commercialisation to explore the role of knowledge transfer intermediary organisations in different countries, especially in CEE countries.

To achieve the aim of the study, we also applied empirical studies relying on multiplecase study methodology (Lin, 2018), which allows both an in-depth examination of each case and the identification of contingency variables that distinguish each case from the other. Moreover, multiple-case studies were used to gain insight into explanatory process based on cross-case analysis externally validating the findings from a single case study. Information was gathered through computer-assisted Web interviews by means of an on-line service (LimeSurvey). The questionnaires remained opened and assumed a conversational manner allowing respondents to describe their comments and opinions.

Through internet searches, the number of commercialisation intermediary institutions were identified and contacted via e-mail or phone requesting participation in the study. We also used the database of Czech organisations publicly available online, facilitated by Andera and Lukeš (2016).

Within each research institution (university, research institute, academy of science, etc.) a different type of commercialisation intermediary structure exists, depending on the chosen commercialisation path. Some research institutions adopt internal structure in a form of, e.g. TTO or a university business incubator. Instead, some institutions establish an external entity in the form of an enterprise wholly owned by the university like SPVs or SPEs. Alternatively, technology parks (science parks, science and technology parks, technoparks) or scientific and industrial centres also exist. Therefore, to characterize research participants, each of the respondents (commercialisation intermediary institutions' representative) was researched to determine which type of structure and which region of the country represent. The scientific disciplines in which R\&D results are commercialised were also identified according to the International Standard Classification of Education (OECD, 2007). Table 1 reports the key characteristic of these institutions and their geographical locations are presented in Figure 2 (map of Poland) and Figure 3 (map of the Czech Republic). Regions for analysis in Poland were chosen based on the European patent application statistics from 2018, often used as an indicator for commercialisation performance (European Patent Office, 2019). Hence, we have covered regions with high (like Mazowieckie) and low shares of total applications (like Warmińsko-Mazurskie or Kujawsko-Pomorskie).

Qualitative analysis was designed according to the following techniques: data categorisation, data contextualisation, preliminary within case analysis and cross-case analysis (Yin, 2018). It allowed us an in-depth investigation of $\mathrm{KBE}$ and commercialisation process in its real word context and to gather different variables of interest relying on multiple sources of evidence (documentation, interviews) in a triangulating fashion. The 


\begin{tabular}{l} 
JEEE \\
15,1 \\
\\
10 \\
\hline
\end{tabular}

Table 1.

The studied commercialisation intermediary institutions

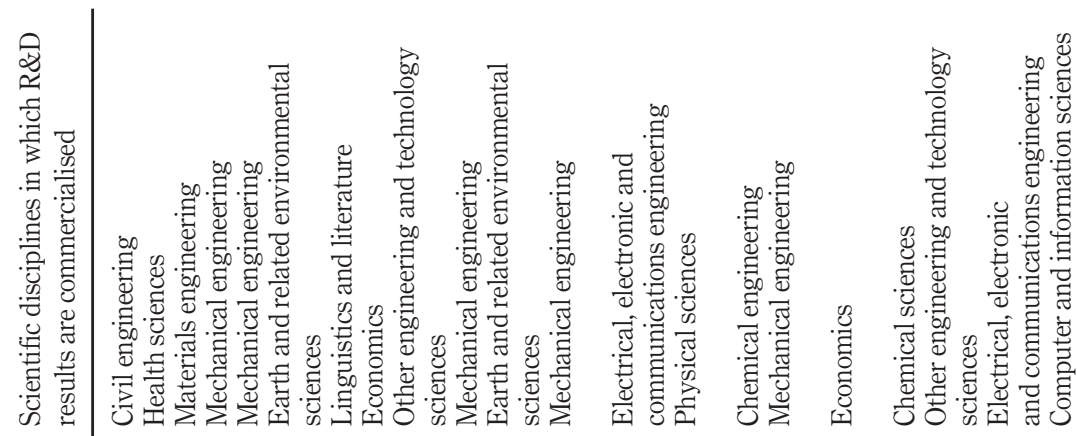
낭.

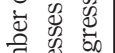

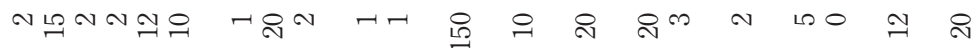

艺苋芑

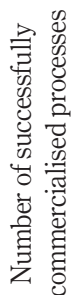

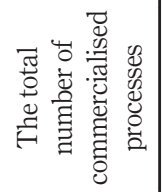

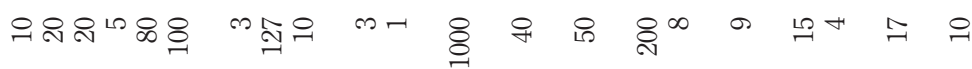

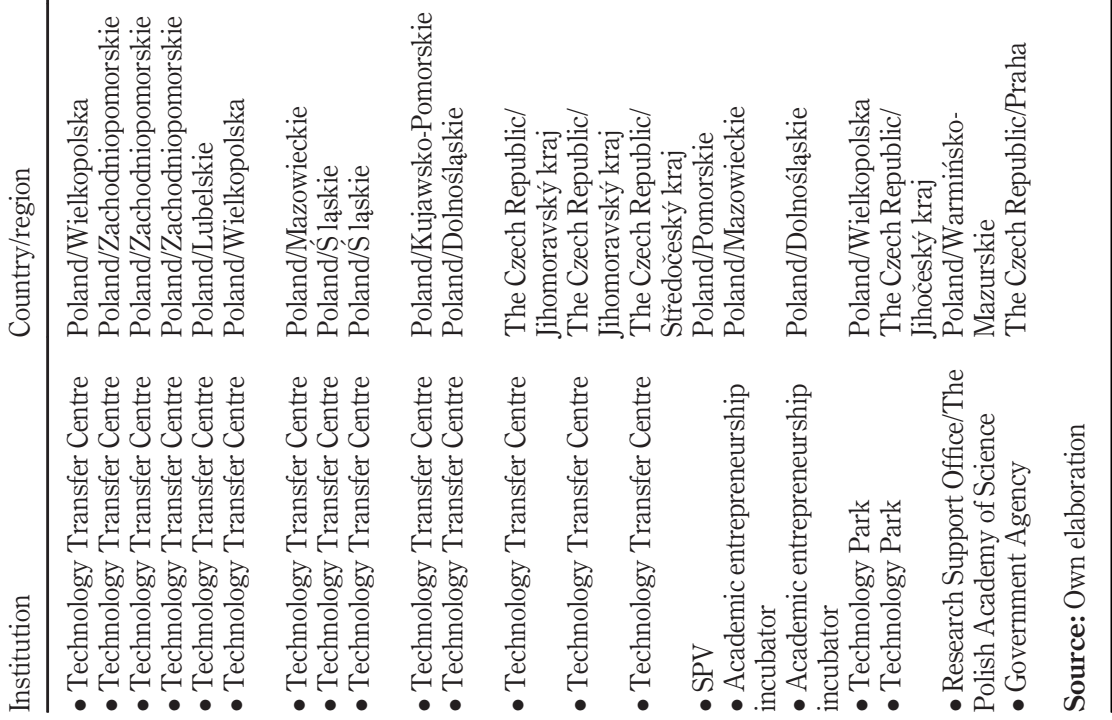




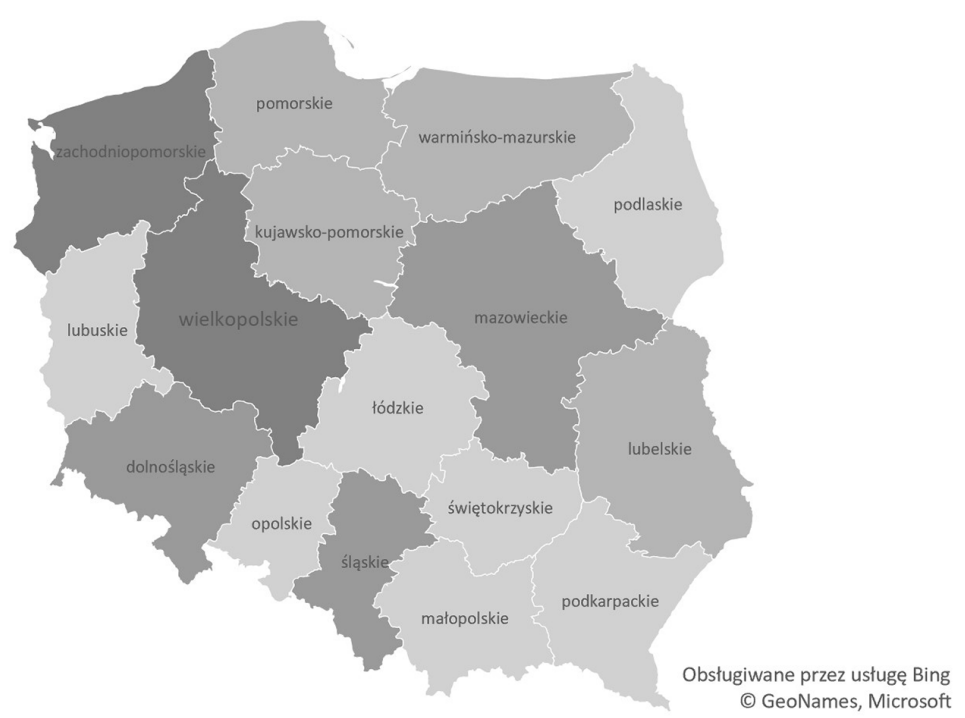

Source: Own elaboration

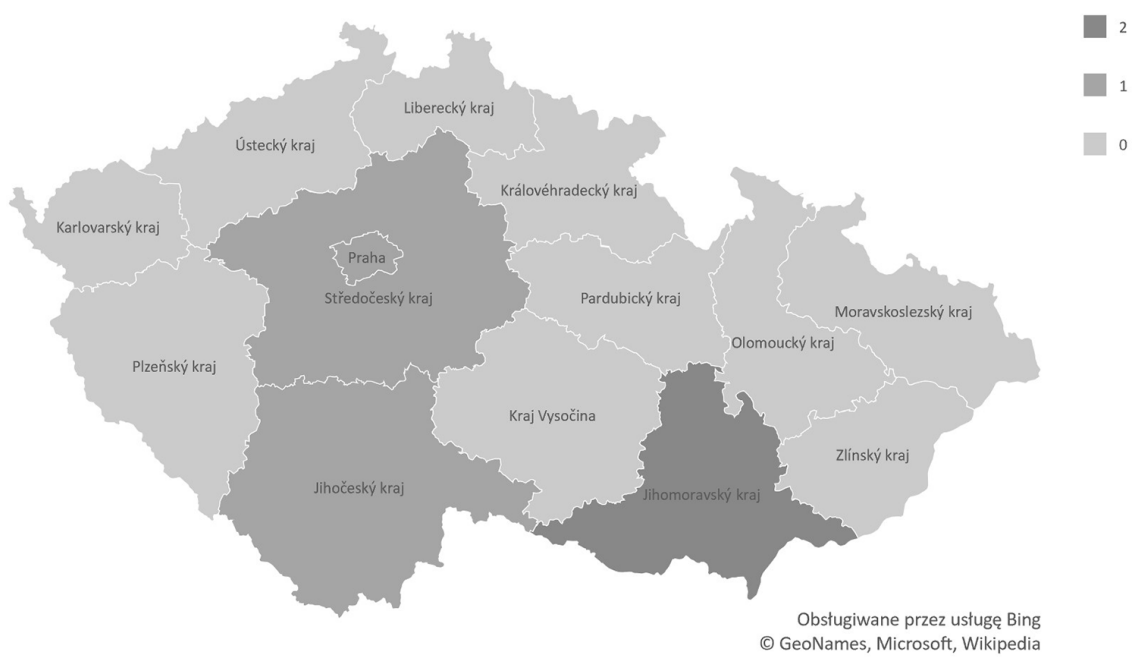

Source: Own elaboration

studied population was homogenous; the research content was precisely structured and focused, which allowed us to reach the saturation point by 21 interviews. The data has been precisely reviewed by the authors who considered theory as a filter to organised collected data (Yin, 1994). We base on the assumption that institutional and geographical conditions can impact the knowledge-based opportunities exploitation between different national
Who really acts as an entrepreneur

Figure 2.

Geographical location of studied commercialisation intermediary institutions in Poland

Figure 3.

Geographical location of studied commercialisation intermediary institutions in the Czech Republic 
JEEE

15,1

economies (Hayter, 2013). First, we define briefly the institutional change in CEE, and especially actual institutional ecosystem supporting KBE (Part I of the questionnaire titled "The commercialisation of university-based research"). Then, we try to explore the following elements of research commercialisation seen as the entrepreneurial process: what was the motivation for research commercialisation, what was the nature of the knowledge transferred (tacit or encoded), who recognised the business opportunity and who changed it into the business conception and what kind of entrepreneurial capabilities they possessed and who organised the financial resources (Part II of the questionnaire titled "The importance of academic entrepreneurship in research commercialisation").

The research was not free of limitations. Firstly, all the visual, non-verbal clues that can facilitate contextualising the interviewee as in the face-to-face interview might be lost. Secondly, the risk of reflexivity and response biases (research participants provides what interviewer want to hear) was also substantial. Thirdly, whilst questionnaire for the Czech Republic participants was introduced in English it might have impacted on the research quality (it was possible to misunderstand or inaccurately understand some questions).

\section{Results and discussion}

The main findings respond to both the confirmatory and exploratory character of the study. Firstly, based on a literature search of leading management journals, we identify articles that used empirical data from KBE and commercialisation to confirm the conceptual representation of the commercialisation as an entrepreneurial process. The empirical evidence that was analysed indicates that research institutions and universities under the influence of different contextual factors adopt dissimilar commercialisation pathways.

\subsection{Key characteristics of the commercialisation process in Central and Eastern European economies}

To better understand key characteristics of the commercialisation process in CEE economies, we investigated different commercialisation systems (Table 1). Our research suggests that TTOs were most often chosen organisational form to support commercialisation followed by academic entrepreneurship incubators, technology parks and SPVs of the universities. There are also other units involved in the process like government agency, research support office of the Polish Academy of Sciences or the centre of knowledge transfer and innovation as well as commercialisation functioning inside the university's business incubator. Therefore, we suggest different organisational forms that are crucial to the effectiveness of commercialisation in terms of their transaction outputs or the ability to coordinate licensing and patenting (Markman et al., 2008). In the line of this research, we furthermore observed large discrepancies in the number of R\&D results commercialisation processes that a single organisation participated in the last five years. This is clear when comparing the cases of institution 11 with one commercialised process to institution 12 with 1,000 . Also, the number of successfully finalised processes varied from 1 (Case 11) to 800 (Case 12). As one respondent admits: "We have been operating just for one year and the profile of our university is rather narrow - social science and humanities. Therefore, there are no inventions that can be licensed or sold." This demonstrates the advancement in commercialisation by individual entities and their various sizes (e.g. a single TTO versus a technology park) and the lifetime of the institution. The effectiveness of a dedicated organisation appears to be more likely for institutions that commercialise R\&D results in technical and engineering disciplines.

Besides various organisational advancement in commercialisation, the differences in the subject of $R \& D$ results commercialisation have also emerged from empirical evidence (Table 2). 
We applied classical categorisations of research introduced in Frascati Manual as "basic research," "applied research" and "experimental development" commonly used for statistical and evaluative purposes.

The empirical analysis of data presented in Table 2 also reveals that there are several models of the commercialisation process. Direct commercialisation was the most commonly chosen path for research commercialisation with the emphasis on licensing rather than patenting. As a rule, direct commercialisation is to be handled by intermediary entities that reflect entrepreneurship (Hindle and Yencken, 2004). Consistent with Siegel and Wright (2015), this represents a more traditional mode of technology commercialisation and has also been the dominant route for commercialisation in countries with a much longer history of technology transfer like the USA (Lockett et al., 2005). Although, recently increased attention has been devoted to the university-based spin-off creation that characterise indirect commercialisation. Still, in Poland and the Czech Republic this is not a common practice (three cases). Clarysse et al. (2011a) and Urbano and Guerrero (2013) concluded that academics vary in their entrepreneurial attitudes, which is one of the core components in the spin-off formation. Clarke (1998) based on qualitative analysis of Western European universities found out that universities with more entrepreneurial culture tend to establish more spin-off companies, as well as universities with clear strategy for spin-off formation and management (Lockett et al., 2003).

According to Boh et al. (2016), there are two models of university entrepreneurship ecosystems: systematic, with deep traditions of entrepreneurial cultures like MIT or Stanford, and organic based on the entrepreneurial resources provided by coordinated system for technology transfer (Harvard, UC Berkeley) and focusing on basic research rather than applied research. As Table 2 indicates, commercialisation is frequently related to more applied research and experimental development as a result of national public research systems also observed in other countries (Kergroach et al., 2018). Although, in line with Stokes (1997), recognising the importance of use-inspired basic research (noticed in three cases), described as "Pasteur's Quadrant," can significantly maximise fundamental research contribution to industry and society (Larsen, 2011). Considering different institutional goals and concomitant organisational conditions, we cannot adopt the same classification.

However, we noticed some similarities with typology of organisational models proposed by Schoen $e$ t al. (2014) for Western European universities. Three main types emerge in our practice as follows:

(1) the classical TTO that exclusively serves one organisation and is discipline integrated, which means that decisions about technology transfer are taken at the institutional level with the same rules and processes for all the departments (Case 1-6, 8-14 and 20);

(2) autonomous TTO which is very similar but with a higher degree of autonomy (Case 7 and 15); and

(3) discipline-integrated technology transfer alliance, an external institution that serves several universities and scientific institutions (Case 16-19 and 21).

Still, the decision over what and how to commercialise in terms of academic discoveries is multifaceted as previously stated by other authors (Lee and Stuen, 2016) and observed in our studies. Scientists differ in their academic engagement with business reliant upon their individual characteristics including demographics, career goals, productivity and motivation (Perkmann et al., 2013). As one respondent claims: "There is lack of willingness and determination of scientists, focusing only on obtaining points based on their publication 
JEEE
15,1

14

Table 2.

Key characteristics of the commercialisation process

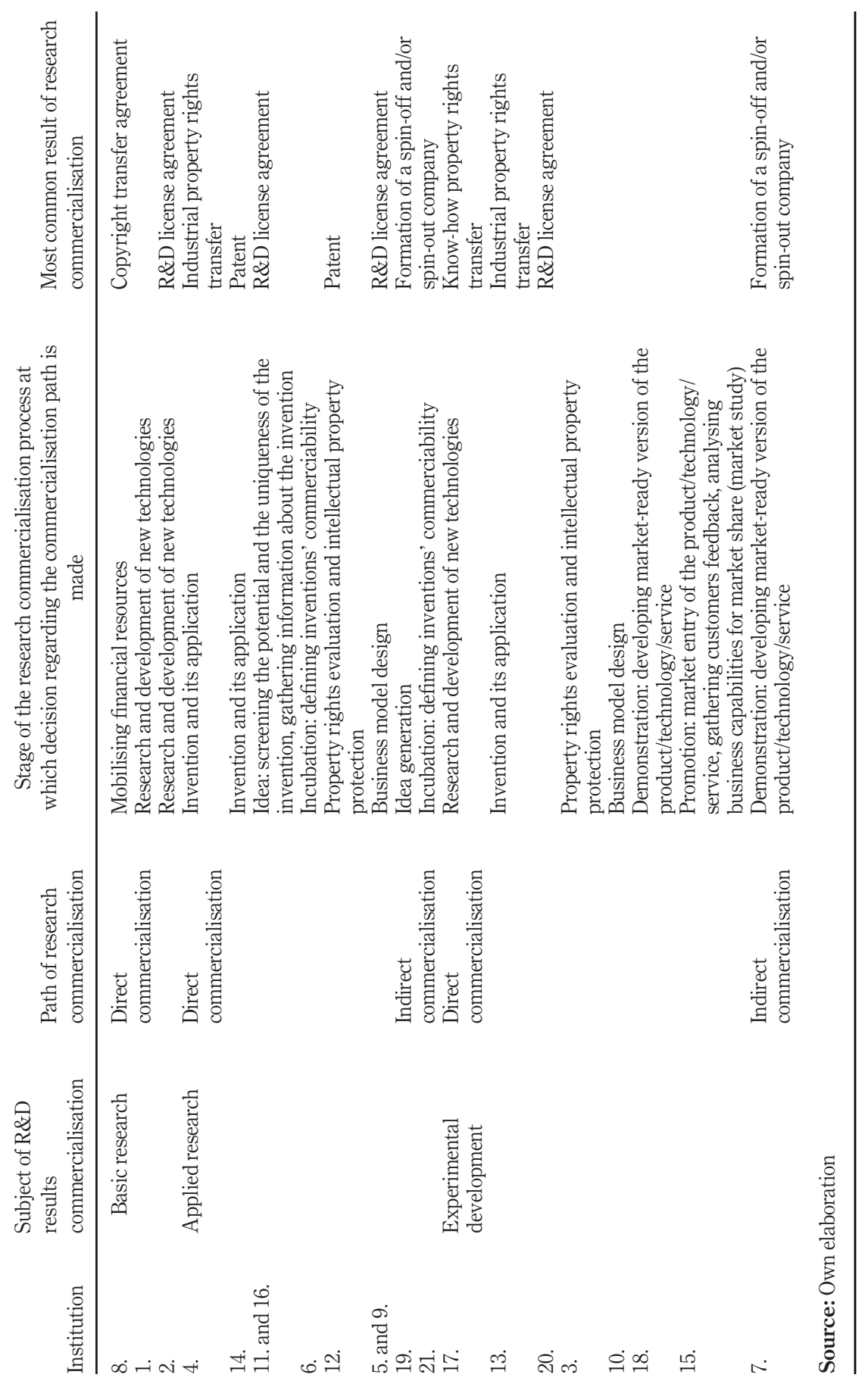


rates and citations instead of conducting useful scientific research suitable for commercialisation."

Besides, commercialisation is related to institutional framework and legal aspects. In Poland, the Ministry of Science and Higher Education based on the Higher Education Act, art. 86c leaves it up to the higher education institutions (HEI) to develop their own commercialisation systems, specifying who receives the property rights and on what terms. Internal regulations also lay down rules regarding the distribution of profits. To commercialise the research outcomes thorough indirect commercialisation, HEI usually establish SPVs to set up further spin-offs (Szulczewska-Remi, 2016). Just recently (based on the Regulation of the Ministry of Science and Higher Education from February 22, 2019), the evaluation of HEI takes into account the commercialisation of research results and experimental development services. Still, the sale of other experimental R\&D services (without funds for the implementation of projects financed by the National Centre for Research and Development and the National Science Centre and the Minister of Science and Higher Education, funds for financing international scientific cooperation) constitute only $1.7 \%$ of total HEI operating revenues (Statistics Poland, 2020a). In the Czech Republic, the legislative framework on public funding of research, experimental development and innovations is set out in Act No 130/2002. An extensive amendment of the act is currently under preparation, and it should primarily introduce support for innovations and new instruments other than subsidies to fund research, development and innovation (National Reform Programme of the Czech Republic, 2020).

Given the uncertainty over how valuable a scientific discovery will be chosen, the commercialisation path is subjective to the aspects such as the quality of prior research, differences in infrastructure and institutional environment (Audretch et al., 2014), the effectiveness of commercialisation intermediary organisation within university or the university's investment in technology transfer resources. Consequently, each scientific institution in CEE countries must take its characteristics into account when organising its technology and knowledge transfer.

Innovations introduced to the market through the entrepreneurial process of research commercialisation are expected to have a great impact on the building of the KBE. For that reason, the creation of innovative start-ups contributes to the economic growth and development (Colombelli, 2016). To achieve this goal, the investments in R\&D and innovations are necessary, as well as the strong cooperation between universities and business enterprises, which are particularly insufficient in CEE countries. Poland and Czechia are just starting to establish conditions for enhancing research commercialisation and intellectual property protection. The number of patents is still low, given the number of researchers per thousand population (7.2 in Poland and 7.6 in Czechia) (OECD, 2019). According to the EOP Patent Index (European Patent Office, 2019), in 2019 Poland fielded only 469 (12.2 per million inhabitants) patent applications and 231 were granted, whereas the Czech Republic filed 198 patent applications (18.5 per million inhabitants) and 172 were granted.

According to Correia et al. (2018), Central, Eastern and South-Eastern European countries differ in the innovation investment patterns in comparison to the other European countries owing to the different financing conditions. However, in 2019 gross domestic expenditure on R\&D (GERD), the main indicator of R\&D activity, increased by $18.1 \%$ compared to the previous year. The R\&D intensity ratio (GERD to GDP) reached the level of $1.32 \%$, of which higher education expenditure on R\&D accounted for 0.47\% (Statistics Poland, 2020b). In 2019, total expenditure on R\&D in the Czech Republic represented 1.94\% of GDP (Czech Statistical Office, 2019). This reflects, on the one hand, that both countries show progress in increasing their R\&D intensities, and, on the other hand, the importance of private sector 
investments in the financing of much of domestic $R \& D$ needed to foster research commercialisation.

\subsection{Research commercialisation as an entrepreneurial process}

In the second part of the study, we adopted the perspective of entrepreneurship as a conduit of knowledge spillover in the research commercialisation process (Audretch and Keilbach, 2007). Knowledge spillovers are generated by universities or incumbent firms through their R\&D departments; however, the way of introducing new products or services into the market can manifest in different forms such as university spin-offs or through licensing. For the purpose of knowledge commercialisation, the technology transfer intermediary organisations are established at the universities, although their effectiveness in this process is not fully recognised yet (Carrick, 2014). For a better understanding of the importance of $\mathrm{KBE}$ in the whole process, we investigated the entrepreneurial competences of the scientific team members, as well as the complementary role of transfer intermediary organisations in selected CEE countries in two important aspects of entrepreneurship: entrepreneurial opportunity recognition and entrepreneurial activities undertaking. According to Witt and Zellner (2005), the academic knowledge transfer from universities into the commercial applications requires some essential knowledge-based entrepreneurial services such as: business opportunity recognition, creation of the firm conception, resources (tacit or encoded knowledge) gathering and coordination or their integration into the earlier business conception.

The results revealed the important role of scientists (research team) in the process of research commercialisation (Table 3). Usually, research commercialisation processes were based on tacit knowledge, as the subject of commercialisation was closely related to the author (scientist). Moreover, the respondents declared it was not possible to use knowledge and technology without the author's (scientist's) participation and involvement, also after commercialisation and implementation of new solution, regardless its form. Only 3 out of 21 respondents in both countries indicated the encoded character of the knowledge transferred, which means the direct participation of the author (scientist) was not necessary, because properly codified knowledge could be reproduced and used by other market participants. Respondents recognised that proposed distinction was difficult to justify.

The research team seemed to have also the most important role in recognising the commercial potential of R\&D results, noticing market opportunities or customer value (15 cases out of which 11 indicated in the first place), however, the substantial role of other actors in this aspect of $\mathrm{KBE}$ is also firmly marked. Thus, the second and the third position in the ranking should be given to the business partners ( 12 cases, out of which four indicated in the first place) and intermediary institutions such as a technology transfer centre (ten cases, out of which five indicated in the first place). These results confirm our assumption that entrepreneurial function of opportunity discovery can be to some point shared between different actors in the science commercialisation ecosystem, however, the scientist does remain as the central figure at this stage of an entrepreneurial process, which is related to the market opportunity discovery. What is surprising in this cultural context, our study suggests stronger than expected cooperation with business partners. It is important, because the university-business cooperation can be considered as a barrier or a driving factor for academic entrepreneurship (Davey et al., 2016).

Among the most frequent drivers of a scientist's decision on research commercialisation, in our study, was research grant reward and patent reward. On the other hand, running one's business and contributing to the innovativeness of enterprises and the economy seemed not to be the most frequent motivations for starting the whole process. It is 

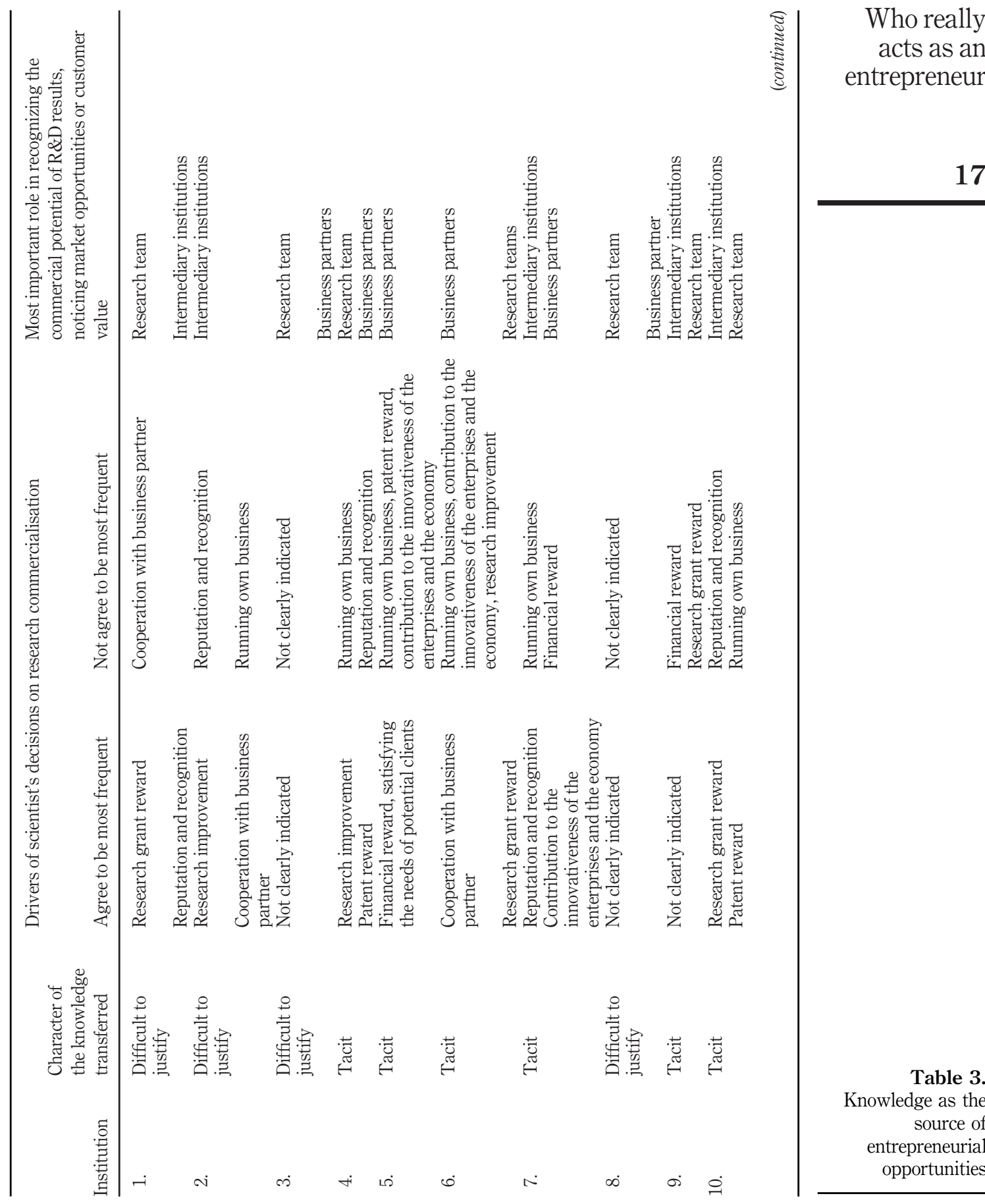


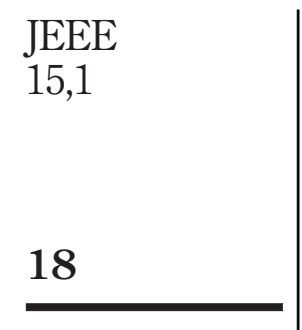

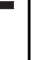

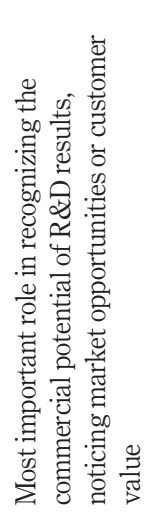

:

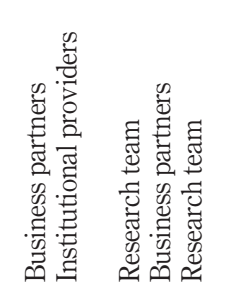

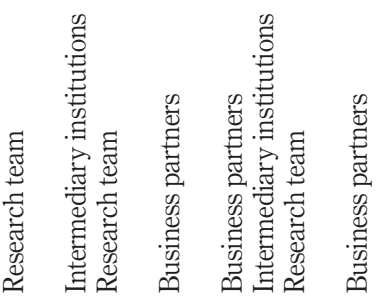

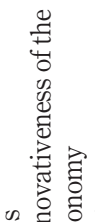

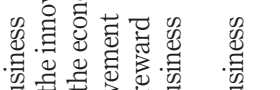

के

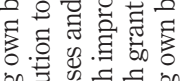

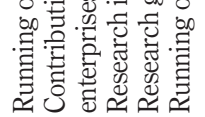

点

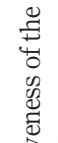

突

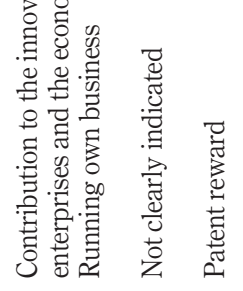

焉

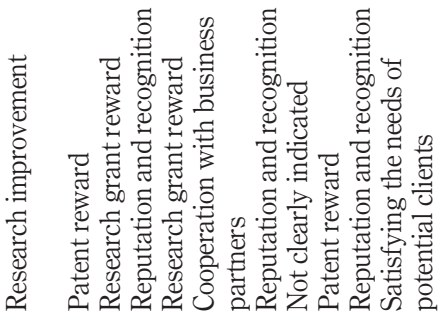

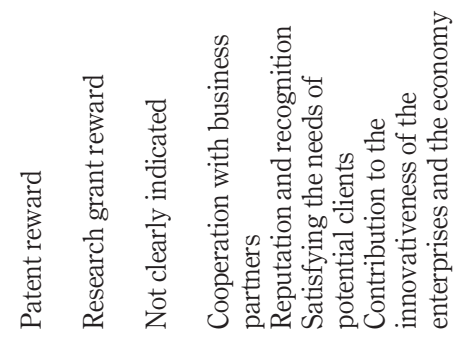

Table 3.

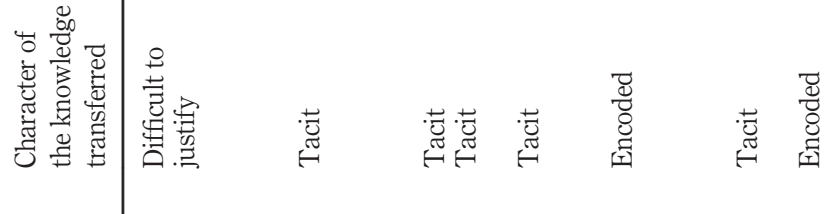

营

บิ

ஸ்ய மோ ம்

$\stackrel{\infty}{\sim}$ 


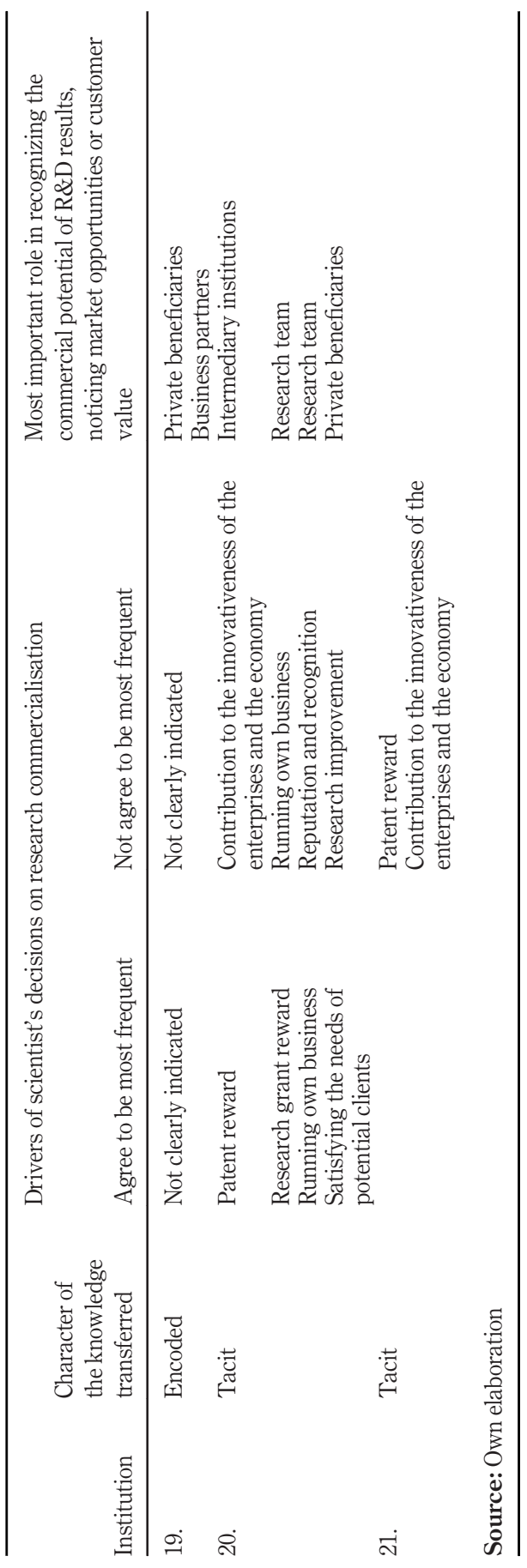


JEEE 15,1

consistent with the study of O'Gorman et al. (2008), who found that "scientists take account of traditional academic rewards when considering the payoffs of commercialisation activity."

When it comes to the new venture creation as the result of research commercialisation, the research team is also the main author of the new organisation's business concept or model, followed by home university or institute units (Table 4).

To validate the entrepreneurial competences of scientific team engaged in the commercialisation processes, we introduced, based on Morris et al. (2013), the concept of competences, that was easier to evaluate by the representatives of intermediary institutions, rather than the measurement of traditional personality traits known as "Big Five" or "Big Seven." Moreover, this approach is related to knowledge and skills needed in the entrepreneurial process (e.g. the ability to accumulate resources).

Intermediary institutions' representatives were asked to evaluate different aspects of entrepreneurship such as: creativity, recognition and evaluation of market opportunities, risk propensity, perseverance, expertise knowledge, team building skills, ability to accumulate financial resources, ability to organise technical facilities, ability of customer needs analysis, cooperation with external partners (networks building) and self-confidence of the members of the scientific team (Morris et al., 2013).

The results suggested that the most important pillars of KBE in the investigated CEE countries were expertise knowledge, creativity and self-confidence. These characteristics should be considered as a good background for the engagement of academics in the research commercialisation process. The studies of Kalar (2020) show that engagement in entrepreneurial activities requires not only entrepreneurial orientation but also self-confidence in their ability to be creative.

The weakest of the entrepreneurial capabilities, with the lowest evaluation from intermediary institutions representatives, were for both countries: analysis of customer needs/market research and risk propensity. Other studies also confirm that risk attitude is an important factor affecting commercialisation as an entrepreneurial process. For example, risk involved in the process was also important factor affecting scientists' entrepreneurial intentions at Spanish universities (Miranda et al., 2017).

Also, the ability to recognise and evaluate market opportunities was rather at the moderate level or below in both studied CEE countries. So even if the role of research team in entrepreneurial opportunities recognition is significant, such abilities, together with market opportunity evaluation need support from the part of properly qualified staff of internal or external institutions. Additional important competences: team building skills and the ability to accumulate financial resources were evaluated at the moderate level in both countries.

As the response for some deficiencies in academics' entrepreneurial competences, the role of intermediary institutions in research commercialisation was explored in our study. These organisations see their role mainly in searching for market orders and creating project teams, intellectual property management and evaluating of inventions' commercialisation potential. Also, business model, development, and expansion consulting, as well as finding a source of financing from investors were quite highly evaluated. The role of intermediary institutions could be defined as the provision of different services and access to resources in the science commercialisation (Clayton et al., 2018), however, some part of those activities, should be considered as strictly related to the entrepreneurial capabilities (Figure 4).

\section{Conclusions}

In the age of digitalisation and the Fourth Industrial Revolution, the business applications of such technologies as artificial intelligence or the Internet of Things create new conditions 


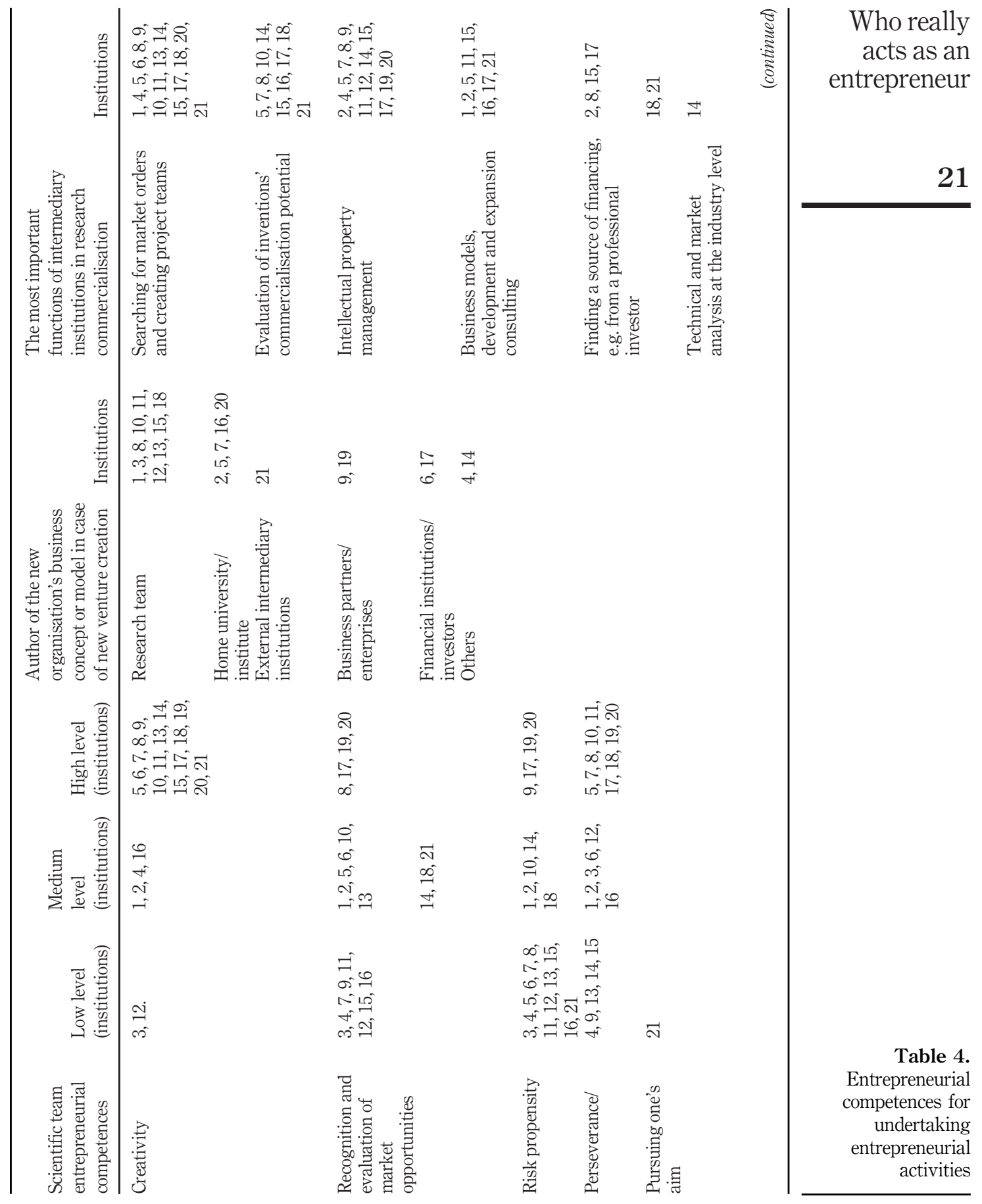


JEEE

22

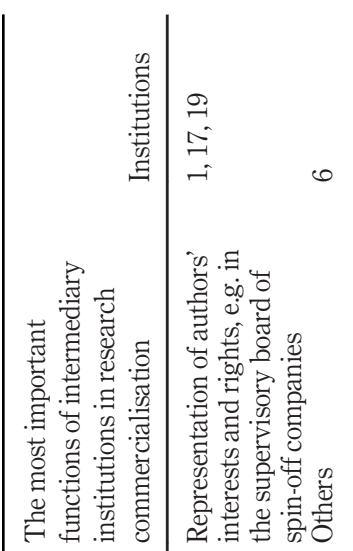

:

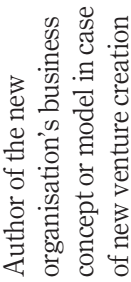

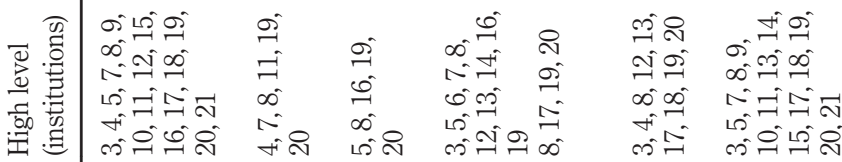

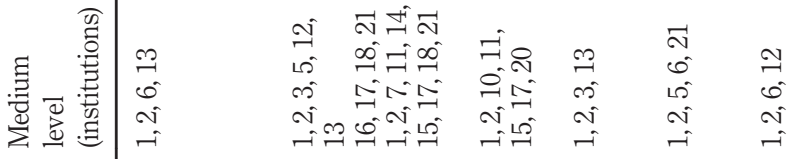

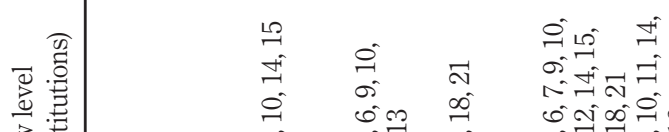

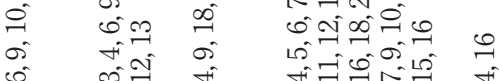

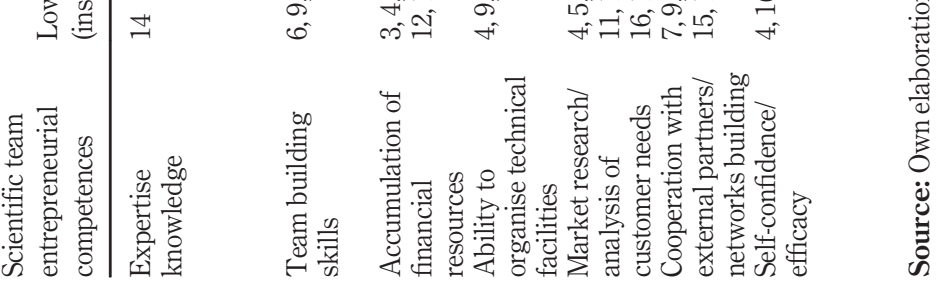

Table 4. 


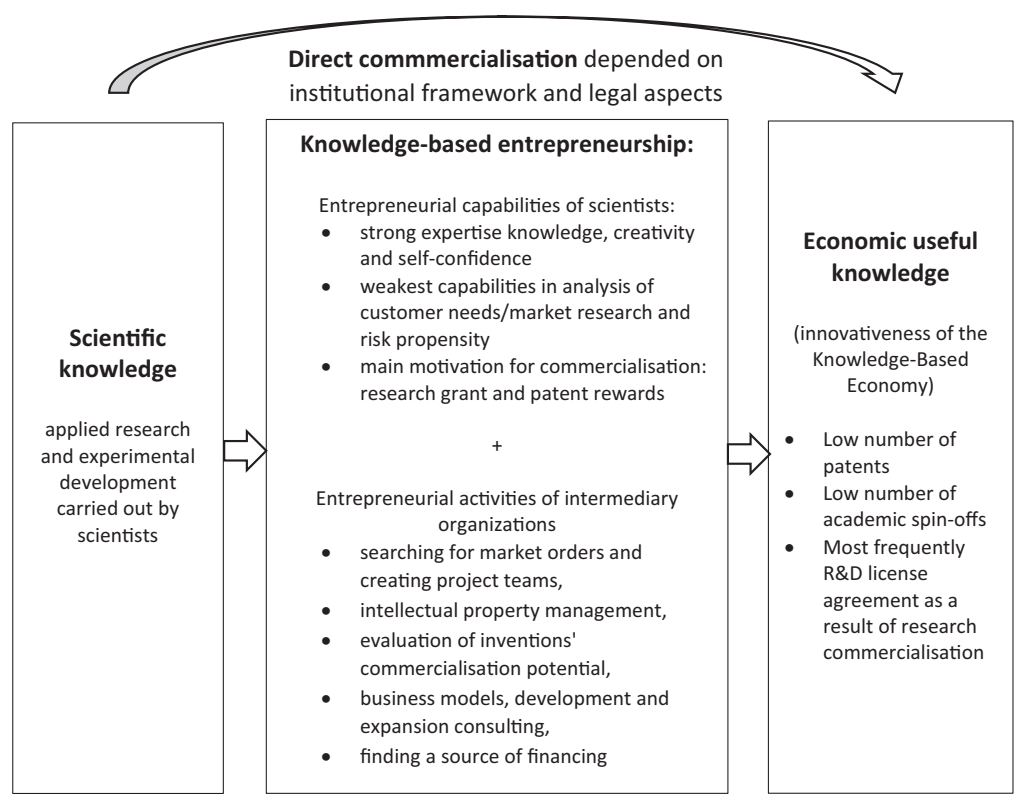

Source: Own elaboration
Who really

acts as an

entrepreneur

23

Figure 4.

Research

commercialisation as

an entrepreneurial

process in Poland and

the Czech Republic

and challenges for entrepreneurs and the whole European economy. The capacity of the European economies to innovate is related not only to the different levels of technological readiness but also more importantly to the commercialising capabilities of HEIs in these countries (Cellary, 2019; Caiazza, 2013; Correia et al., 2018). Moreover, only few studies in science commercialisation have tried to develop conceptual frameworks considering $\mathrm{KBE}$ and knowledge commercialisation in their relations and subsequential roles. Also, over the past couple of years, literature in this area has expanded mainly relying on observations in the USA and Western European countries. Hence, this research allowed us to collect findings from two CEE countries for which data are still insufficient but can significantly contribute to the theory development.

To explore the complementary entrepreneurial role of knowledge transfer intermediary organisations in Poland and the Czech Republic, empirical studies relying on multiple-case study methodology and cross-case analysis covering 21 cases of commercialisation intermediary institutions were carried out. The study confirmed that the process of research commercialisation depends on internal factors related to the characteristics of individual members of the scientific community (e.g. entrepreneurial competences and cognitive structures), and the external factors concerning the institutional environment and the whole system of academic entrepreneurship and research commercialisation support. It can be concluded that scientists in CEE countries are the central figures of the commercialisation process in terms of entrepreneurial opportunity recognition, as they possess the tacit knowledge, core resource for the research commercialisation process. However, they need support from university-related units or external intermediary organisations in many entrepreneurial activities (e.g. opportunity recognition or the evaluation of an invention's commercialisation potential, team building or business model development). 
JEEE

15,1

Scientists in CEE countries still have less market-driven motivations, as they concentrate on science-related rewards. Because of that, and some deficiencies in entrepreneurial competences (e.g. low level of risk propensity), the creation of a KBE in these countries complementary requires intermediary organisations. Different aspects of $\mathrm{KBE}$ which support successful research commercialisation in CEE countries are the common effort of scientists and the intermediary organisations, so it is difficult to treat the majority of scientists in these countries, engaged in the research commercialisation processes, as the self-sufficient and independent entrepreneurs. At the current stage of economic growth and institutional ecosystem development for supporting knowledge transfer into the market, intermediary organisations should be treated not only as the external technical providers of services or resources needed in the commercialisation process but also as an important and integral part of the phenomenon of KBE manifested in providing essential entrepreneurial activities affecting scientists' entrepreneurial capabilities and their cognitive structures. Based on the study we conclude that academic entrepreneurship will not develop and foster a KBE in the studied CEE countries, until public policy will support the whole complex process of research commercialisation and its principal actors (scientists, universities, intermediary institutions and business partners) as collective entrepreneurs.

Both countries experienced a successful economic transition into market economies and their institutional conditions for running knowledge-based firms are constantly changing. Still, the history of knowledge commercialisation and its intermediating entities in these countries are relatively young. Universities and other scientific institutions are effective vehicles for knowledge and technology transfer providing intellectual property; however, spin-off company creation is not a common practice. Also, the willingness to run one's own business and contributing to the innovativeness of the economy are not the most important drivers of a scientific team's motivation for research commercialisation. However, expertise knowledge, creativity and self-confidence admitted by the respondents in both countries can be the optimistic sign for the future efforts in fostering innovativeness of CEE countries.

There are still some significant constraints observed in the institutional environment which can be because of informal and cognitive aspects of entrepreneurial capabilities of potential innovators and entrepreneurs. For that reason, universities' internal policies should be defined to support formal institutional framework including intellectual property rights protection, providing rules and guides for the commercial exploration of research discoveries. Also, the role of commercialisation intermediary institutions acting as KBE providers should be fully recognised. Given the importance of their potential in developing entrepreneurial competences of the academic community or cooperation with the research team to provide entrepreneurial competences for research commercialisation, it is, therefore, desirable that the policy makers should define their strategic role in academiaindustry interaction. They might consider, for example, high education institution evaluation through the prism of their commercialisation efficiency. Because Poland and the Czech Republic have recorded a substantial increase in expenditure on $R \& D$, confirming the strong commitment to improve their innovation performance, more financial initiatives are required to tighten the cooperation between science and industry especially coming from regional innovation agencies (e.g. in a form of joint research grants including intermediary involvement). However, further research could validate the results in extensive quantitative study. Empirical work is necessary to better understand how scientists in CEE countries perceive their entrepreneurial competences in their research commercialisation process. 


\section{References}

Acs, Z.J., Audretsch, D.B. and Lehmann, E.E. (2013), "The knowledge spillover theory of entrepreneurship”, Small Business Economics, Vol. 41 No. 4, doi: 10.1007/s11187-013-9505-9.

Acs, Z.J., Braunerhjelm, P., Audretsch, D.B. and Carlsson, B. (2009), "The knowledge spillover theory of entrepreneurship”, Small Business Economics, Vol. 32 No. 1, pp. 15-30, doi: 10.1007/s11187-0089157-3.

Alvarez, S.A. and Busenitz, L.W. (2003), "The entrepreneurship of resource-based theory”, Journal of Management, Vol. 29 No. 3, pp. 285-308.

Andera, M. and Lukeš, M. (2016), "Business incubators in the Czech Republic: well spent money?", In Proceedings of the 4th International Conference Innovation Management, Entrepreneurship and Corporate Sustainability.

Audretch, D.B. and Keilbach, M. (2007), "The localization of entrepreneurship capital - evidence from Germany", Jena Economic Research Paper, Vol. 2007-029

Audretch, D.B., Lehmann, L.L. and Wright, M. (2014), “Technology transfer in a global economy”, The Journal of Technology Transfer, Vol. 39 No. 3, pp. 301-312, doi: 10.1007/s10961-012-9283-6.

Audretsch, D.B. and Kayalar-Erdem, D. (2005), "Determinants of scientist entrepreneurship: an integrative research agenda”, in Alvarez, S.A., Agarwal, R. and Sorenson, O. (Eds), Handbook of Entrepreneurship Research. International Handbook Series on Entrepreneurship, Vol 2. Springer, Boston, MA, doi: 10.1007/0-387-23622-8_6.

Belitski, M., Aginskaja, A. and Marozau, R. (2019), "Commercializing university research in transition economies: technology transfer offices or direct industrial funding?”, Research Policy, Vol. 48 No. 3, pp. 601-615.

Bercovitz, J. and Feldmann, M. (2006), "Entrepreneurial universities and technology transfer: a conceptual framework for understanding knowledge-based economic development", The Journal of Technology Transfer, Vol. 31 No. 1, pp. 175-188.

Boh, W.F., De-Haan, U. and Strom, R. (2016), "University technology transfer through entrepreneurship: faculty and students in spinoffs", The Journal of Technology Transfer, Vol. 41 No. 4, pp. 661-669, doi: 10.1007/s10961-015-9399-6.

Bradley, S.R., Hayter, C.S. and Link, A.N. (2013), "Models and methods of university technology transfer", in Department of Economics Working Paper Series, University of NC.

Brendzel-Skowera, K. (2016), "Paradoksy w rozwoju przedsiębiorczości akademickiej" (paradoxes in the development of academic entrepreneurship)", Prace Naukowe UE we Wroclawiu, Vol. 419, pp. 33-42.

Brooks, C., Vorley, T. and Gherhes, C. (2019), "Entrepreneurial ecosystems in Poland: panacea, paper tiger or Pandora's box?”, Journal of Entrepreneurship and Public Policy, Vol. 8 No. 3, pp. 319-338.

Caiazza, R. (2013), "The Italian system of innovation: strengths and weaknesses", Journal of Chinese Entrepreneurship, Vol. 5 No. 2, pp. 161-172.

Capat, G. and Sandelin, J. (2004), "Models of, and missions for, transfer offices from public research organizations", available at: http://otl.stanford.edu/documents/JSMissionsModelsPaper-1.pdf

Carrick, J. (2014), "Technology based academic entrepreneurship: how little we know", Journal of Strategic Innovation and Sustainability, Vol. 9, pp. 63-75.

Cellary, W. (2019), "Non-technical challenges of industry 4.0", in Camarinha-Matos L.M., Afsarmanech, H. and Antonelli, D. (Eds), Collaborative Networks and Digital Transformation, IFIP Advances in Information and Communication Technology, 568, IFIP-Springer, pp. 3-10, doi: 10.1007/978-3-030-28464-0.

Clarke, T. (1998), "Research on corporate governance. Corporate governance", Corporate Governance, Vol. 6 No. 1, doi: 10.1111/1467-8683.00081.

Clarysse, B., Tartar, V. and Salter, A. (2011a), "The impact of entrepreneurial capacity, experience and organizational support on academic entrepreneurship", Research Policy, Vol. 40 No. 8, pp. 1084-1093. 
JEEE 15,1

Clarysse, B., Wright, M. and Van de Velde, E. (2011b), "Entrepreneurial origin, technological knowledge, and the growth of spin-off companies", Journal of Management Studies, Vol. 48 No. 6, pp. 1420-1042.

Clayton, P., Feldman, M. and Lowe, N. (2018), "Behind the scenes: intermediary organizations that facilitate science commercialisation through entrepreneurship", Academy of Management Perspectives, Vol. 32 No. 1, pp. 104-124, doi: 10.5465/amp.2016.0133.

Colombelli, A. (2016), "The impact of local knowledge bases on the creation of innovative start-ups in Italy", Small Business Economics, Vol. 47 No. 2, pp. 383-396, doi: 10.1007/s11187-016-9722-0.

Correia, A., Bilbao-Osorio, B., Kollar, M., Gereben, A. and Weiss, C. (2018), "Innovation investment in Central, Eastern and South-Eastern Europe: building future prosperity and setting the ground for sustainable upward convergence, EIB regional study", available at: https:/www.eib.org/ attachments/efs/innovation_investment_in_cesee_en.pdf

Corsi, C. and Prencipe, A. (2016), "Improving innovation in university spin-offs. The fostering role of university and region", Journal of Technology Management and Innovation, Vol. 11 No. 2, pp. 13-21.

Council for Research, Development and Innovation (2019), "Innovation strategy of the Czech Republic 2019-2030", available at: https://www.businessinfo.cz/app/content/files/engdocs/innovationstrategy-czech-republich-the-country-for-the-future-2019-2030.pdf

Cunningham, J., Menter, M. and Young, C. (2017), "A review of qualitative case methods trends and themes used in technology transfer research”, The Journal of Technology Transfer, Vol. 42 No. 4, pp. 923-956.

Czech Statistical Office (2019), "Total expenditure on R\&D in Czech Republic in 2019”, available at: https://www.czso.cz/csu/czso/statistika_vyzkumu_a_vyvoje

Davey, T., Rossano, S. and Van der Sijde, P. (2016), "Does context matter in academic entrepreneurship? The role of barriers and drivers in the regional and national context", The Journal of Technology Transfer, Vol. 41 No. 6, pp. 1457-1482, doi: 10.1007/s10961-015-9450-7.

Dvorák, I. and Ciharová, K. (2013), “Technology transfer training in the Czech Republic - pilot of European certification”, Procedia - Social and Behavioral Sciences, Vol. 103, pp. 946-953.

Dvouletý, O., Andrea, M., Lukeš, M. and Oravcová, Z. (2017), "Who is really residing in the Czech business incubators?", in Proceedings of the 5th International Conference Innovation Management, Entrepreneurship and Sustainability, available at: https://imes.vse.cz/wp-content/ uploads/2015/08/Conference_Proceedings_IMES_2017.pdf

Dvouletý, O., Longo, M.C., Blažková, I., Lukeš, M. and Andera, M. (2018), "Are publicly funded Czech incubators effective? The comparison of performance of supported and non-supported firms", European Journal of Innovation Management, Vol. 21 No. 4, pp. 543-563.

European Commission (2019), "European innovation scoreboard", available at: https://ec.europa.eu/ growth/industry/policy/innovation/scoreboards_en

European Patent Office (2019), "EOP patent index 2019”, available at: https://www.epo.org/about-us/ annual-reports-statistics/statistics.html

European Union (2016), "Your guide to IP commercialisation", available at: https://www.iprhelpdesk. $\mathrm{eu} /$ sites/default/files/documents/EU-IPR-Guide-Commercialisation.pdf

Fini, R., Rasmussen, E., Wiklund, J. and Wright, M. (2018), "Theories from the lab: how research on science commercialization can contribute to management studies", Journal of Management Studies, Vol. 56 No. 5, doi: 10.1111/joms.12424.

Fitzgerald, C. and Cunningham, J.A. (2016), "Inside the university technology transfer office: mission statement analysis", The Journal of Technology Transfer, Vol. 41 No. 5, pp. 1235-1246.

Fritsch, M., Obschonka, M. and Wyrwich, M. (2019), "Historical roots of entrepreneurship - facilitating culture and innovation activity: an analysis for German regions", Regional Studies, Vol. 53 No. 9, pp. 1296-1307, doi: 10.1080/00343404.2019.1580357. 
Hayter, C. (2013), "Conceptualizing knowledge-based entrepreneurship networks: perspectives from the literature", Small Business Economic, doi: 10.1007/s11187-013-9512-x.

Hayter, C., Nelson, A.J., Zayed, S. and O'Connor, A.C. (2018), "Conceptualizing academic entrepreneurship ecosystems: a review, analysis and extension of the literature", The Journal of Technology Transfer, Vol. 43 No. 4, pp. 1039-1082.

Hindle, K. and Yencken, J. (2004), "Public research commercialisation, entrepreneurship and new technology based firms: an integrated model", Technovation, Vol. 24 No. 10, pp. 793-803.

Jensen, R. and Thursby, M. (2001), "Proofs and prototypes for sale: the licensing of university inventions", American Economic Review, Vol. 91 No. 1, pp. 240-259.

Jolly, V.K. (1997), Commercializing New Technologies: getting from Mind to Market, Harvard Business School Press, Boston, MA.

Kalar, B. (2020), "The role of creativity in the context of academic entrepreneurship", Creativity and Innovation Management, Vol. 29 No. 2, doi: 10.1111/caim.12352.

Kergroach, S., Meissner, D. and Vonortas, N.S. (2018), "Technology transfer and commercialisation by universities and PRIs: benchmarking OECD country policy approaches", Economics of Innovation and New Technology, Vol. 27 Nos 5/6, pp. 510-530, doi: 10.1080/ 10438599.2017.1376167.

Kher, R. and Lyons, T.S. (2020), "University-based venture development organizations", Entrepreneurship Research Journal, Vol. 10 No. 2, doi: 10.1515/erj-2020-0057.

Klincewicz, K. (2011), Dyfuzja Innowacji, Jak Odnieść Sukces w Komercjalizacji Nowych Produktów i Ustug (Diffusion of Innovation, How to Be Successful in Commercializing New Products and Services), Wyd, Wydziału Zarządzania UW, Warszawa.

Klofsten, M. and Jones-Evans, D. (2000), "Comparing academic entrepreneurship in Europe - the case of Sweden and Ireland”, Small Business Economics, Vol. 14 No. 4, pp. 299-309.

Kluczek, A. (2011), "Komercjalizacja technologii jako instrument wsparcia rozwoju gospodarczego" (commercialization of technology as an instrument to support economic development)", in Meredyk, K. and Wildowicz-Siegiel, A. (Eds), Instytucjonalne Aspekty Rozwoju Sektora B+R w Polsce. Od Gospodarki Imitacyjnej Do Innowacyjnej (Institutional Aspects of R\&D Development Sector in Poland. From the Imitation to the Innovative Economy), Wyd. Uniwersytetu $\mathrm{w}$ Białymstoku, Białystok.

Kolympiris, C. and Klein, P.G. (2017), "The effects of academics incubators on university innovation", Strategic Entrepreneurship Journal, Vol. 11 No. 2, pp. 145-170.

Kotlar, J., Massis, A., Wright, M. and Frattini, F. (2018), "Organizational goals: antecedents, formation processes and implications for firm behavior and performance", International Journal of Management Reviews, Vol. 2, pp. S3-S18.

Kozmetzky, G., Williams, F. and Williams, V. (2004), "New wealth. Commercialization of science and technology for business and economic development", Praeger, Westport, CT.

Krueger, N.F. (2000), "The cognitive infrastructure of opportunity emergence", Entrepreneurship Theory and Practice, Vol. 24 No. 3, pp. 5-23.

Larsen, M.T. (2011), "The implications of academic enterprise for public science: an overview of the empirical evidence", Research Policy, Vol. 40 No. 1, pp. 6-19.

Lee, J. and Stuen, E. (2016), "University reputation and technology commercialization: evidence from nanoscale science", The Journal of Technology Transfer, Vol. 41 No. 3, pp. 586-609, doi: 10.1007/ s10961-015-9430-y.

Linton, J.D. and $\mathrm{Xu}, \mathrm{W}$. (2021), "Research on science and technological entrepreneurship education: what needs to happen next?”, The Journal of Technology Transfer, Vol. 46 No. 2, pp. 393-406, doi: 10.1007/s10961-020-09786-6. 
JEEE 15,1

Lockett, A., Siegel, D., Wright, M. and Ensley, M.D. (2005), "The creation of spin-off firms at public research institutions: managerial and policy implications", Research Policy, Vol. 34 No. 7, pp. 981-993.

Lockett, A., Wright, M. and Franklin, S. (2003), "Technology transfer and universities' spin-out strategies", Small Business Economics, Vol. 20 No. 2, pp. 185-201.

Low, M.B. and Macmillan, I.C. (1988), "Entrepreneurship - past research and future challenges", Journal of Management, Vol. 14 No. 2, pp. 139-161.

Malerba, F., Mani, S., Sterzi, V., Wu, X. and Yudanov, A. (2016), "Knowledge based entrepreneurship and emerging economies", in Malerba, F., Caloghirou, Y., McKelvey, H. and Radosevic, S. (Eds), Dynamics of Knowledge-Intensive Entrepreneurship: Business Strategy and Public Policy, Routledge, New York, NY.

Maresova, P., Stemberkova, R. and Fadeyi, O. (2019), "Models, processes, and roles of universities in technology transfer management: a systematic review”, Administrative Sciences, Vol. 9 No. 3, pp. 1-36, doi: 10.3390/admsci9030067.

Markman, G.D., Siegel, D.S. and Wright, M. (2008), "Research and technology commercialization", Journal of Management Studies, Vol. 45 No. 8, pp. 1402-1423.

Ministry of Infrastructure and Development (2017), "Strategy for responsible development", available at: www.gov.pl/documents/33377/436740/SOR_2017_en.pdf

Miranda, F.J., Chamorro-Mera, A. and Rubio, S. (2017), "Academic entrepreneurship in Spanish universities: an analysis of the determinants of entrepreneurial intention”, European Research on Management and Business Economics, Vol. 23 No. 2, pp. 113-122.

Morris, M.H., Webb, J.W., Fu, J. and Singhal, S. (2013), "A competency-based perspective on entrepreneurship education: conceptual and empirical insights", Journal of Small Business Management, Vol. 51 No. 3, pp. 352-369.

Moutinho, R., Au-Yong-Oliveira, M., Coelho, A. and Manso, J.P. (2016), "Determinants of knowledgebased entrepreneurship: an exploratory approach", International Entrepreneurship and Management Journal, Vol. 12 No. 1, pp. 171-197, doi: 10.1007/s11365-014-0339-y.

Munari, F., Sobrero, M. and Toschi, L. (2018), "The university as a venture capitalist? Gap funding instruments for technology transfer", Technological Forecasting and Social Change, Vol. 127, pp. 70-84.

National Reform Programme of the Czech Republic (2020), available at: https:/ec.europa.eu/info/sites/ info/files/2019-european-semester-national-reform-programme-czech-republic_en_0.pdf

Neves, S. and Brito, C. (2020), “Academic entrepreneurship intentions: a systematic literature review”, Journal of Management Development, Vol. 39 No. 5, pp. 645-704, doi: 10.1108/JMD-11-2019-0451.

Nguyen, T.V., Nguyen, L.T. and Nguyen, H.H. (2018), "Fostering academic entrepreneurship: a qualitative study of invention commercialization in Vietnam", Journal of Developmental Entrepreneurship, Vol. 23 No. 04, pp. 1-23.

O'Gorman, C., Byrne, O. and Pandya, D. (2008), "How scientists commercialise new knowledge via entrepreneurship”, The Journal of Technology Transfer, Vol. 33 No. 1, pp. 23-43, doi: 10.1007/ s10961-006-9010-2.

O’Kane, C., Mangematin, V., Geoghegan, W. and Fitzgerald, C. (2015), "University technology transfer offices: the search for identity to build legitimacy”, Research Policy, Vol. 44 No. 2, pp. 421-437.

OECD (2007), "Working party of national experts on science and technology indicators. Revised field of science and technology (FOS) classification in the Frascati manual", available at: https://www. oecd.org/science/inno/38235147.pdf

OECD (2019), "Main science and technology indicators", Vol. 1019/2, available at: https://www.oecdilibrary.org/docserver/g2g9ff07-en.pdf?expires $=1612861082 \&$ id=id\&accname=ocid74026475\& checksum=B3E8C86ECF314E6778EA220DF0904AC8 
PAP Foundation (2018), available at: http://naukawpolsce.pap.pl/sites/default/files/201807/ RAPORT_Nauki_Zastosowane.pdf

Perkmann, M., Tartari, V., McKelvey, M., Autioa, E., Broströmc, A., D’Este, P., Fini, R., Geuna, A., Grimaldif, R., Hughes, A., Krabel, S., Kitsong, M., Llerenai, P., Lissoni, F., Salter, A. and Sobrero, M. (2013), "Academic engagement and commercialisation: a review of the literature on university-industry relations", Research Policy, Vol. 42 No. 2, pp. 423-442, doi: 10.1016/j. respol.2012.09.007.

Pisano, G.P. (2006), Science Business: The Promise, the Reality, and the Future of Biotech, Harvard Business Press, Boston, MA.

Poppen, F. and Decker, R. (2018), "The intermediary as an institutional entrepreneur: institutional change and stability in triple-helix cooperation”, Triple Helix, Vol. 5 No. 1, pp. 1-22, doi: 10.1186/ s40604-018-0063-7.

Powers, J.B. and McDougall, P.P. (2005), "University start-up formation and technology licensing with firms that go public: a resource-based view of academic entrepreneurship", Journal of Business Venturing, Vol. 20 No. 3, pp. 291-311.

Qian, H. (2017), "Skills and knowledge-based entrepreneurship: evidence from US cities", Regional Studies, Vol. 51 No. 10, pp. 1469-1482, doi: 10.1080/00343404.2016.1213383.

Reyes, C.N. (2016), "Framing the entrepreneurial university: the case of the national university of Singapore", Journal of Entrepreneurship in Emerging Economies, Vol. 8 No. 2, pp. 134-161, doi: 10.1108/JEEE-09-2015-0046.

Schiuma, G. and Lerro, A. (2010), "Knowledge-based dynamics of regional development: the intellectual capital innovation capacity model”, International Journal of Knowledge-Based Development, Vol. 1 Nos 1/2, doi: 10.1504/IJKBD.2010.032585.

Schoen, A., Van Pottelsberghe de la Potterie, B. and Henkel, J. (2014), "Governance typology of universities' technology transfer processes”, Journal of Technology Transfer, Vol. 39, pp. 435-453, doi: 10.1007/s10961-012-9289-0.

Secundo, G., De Beer, C., Schutte, C.S.L. and Passiante, G. (2017), "Mobilising intellectual capital to improve European universities' competitiveness. The technology transfer offices' role", Journal of Intellectual Capital, Vol. 18 No. 3, pp. 607-624.

Shane, S. (2004), Academic Entrepreneurship: University Spinoffs and Wealth Creation, Edward Elgar Publishing, Cheltenham.

Shane, S. and Venkataraman, S. (2000), "The promise of entrepreneurship as a field of research", Academy of Management Review, Vol. 25 No. 1, pp. 217-226.

Siegel, D.S. and Wright, M. (2015), “Academic entrepreneurship: time for a rethink?”, British Journal of Management, Vol. 26 No. 4, pp. 582-595, doi: 10.1111/1467-8551.12116.

Siegel, D., Veugelers, R. and Wright, M. (2007), "Technology transfer offices and commercialization of university intellectual property: performance and policy implications", Oxford Review of Economic Policy, Vol. 23 No. 4, pp. 640-660, doi: 10.1093/oxrep/grm036.

Siegel, D.S., Waldman, D.A. and Link, A.N. (2003), "Assessing the impact of organizational practices on the productivity of university technology transfer offices: an exploratory study", Research Policy, Vol. 32 No. 1, pp. 27-48.

Siemieniuk, L. (2015), "Academic business incubators as an institutional form of academic entrepreneurship development in Poland", Oeconomia Copernicana, Vol. 7 No. 1, pp. 143-159, doi: 10.12775/OeC.2015.010.

Spilling, O.R. (2004), “Commercialization of knowledge-a conceptual framework", In Proceedings from 13th Nordic Conference on Small Business (NCSB) Research.

Statistics Poland (2020a), "Higher education and its finances in 2019", available at: http://stat.gov.pl

Statistics Poland (2020b), "Research and experimental development in Poland in 2019", available at: http://stat.gov.pl 
JEEE 15,1

Stemberkova, R., Zdralek, P., Matulova, P., Maresova, P. and Kuca, K. (2016), “The importance of the evaluation of R\&D in relation to the competitiveness of the Czech Republic", Business Challenges in the Changing Economic Landscape, Springer Cham, Switzerland.

Stokes, D.E. (1997), "Pasteur's quadrant", Basic Science and Technological Innovation, Brookings Institution Press, Washington, DC.

Stuetzer, M., Audretsch, D.B., Obschonka, M., Gosling, S.D., Rentfrow, P.J. and Potter, J. (2018), "Entrepreneurship culture, knowledge spillovers and the growth of regions", Regional Studies, Vol. 52 No. 5, pp. 608-618, doi: 10.1080/00343404.2017.1294251.

Suhaimi, N.S., Abdul Halim, M.A.S. and Hashim, H.A. (2020), "Commercialization of academic research: assessing the perception of academicians at a public university in Malaysia", Journal of Applied Research in Higher Education, Vol. ahead-of-print No. ahead-of-print, doi: 10.1108/JARHE-042020-0071.

Suvinen, N., Konttinen, J. and Nieminen, M. (2010), "How necessary are intermediary organizations in the commercialization of research?”, European Planning Studies, Vol. 18 No. 9, doi: 10.1080/ 09654313.2010 .492584$.

Szulczewska-Remi, A. (2016), "The special purpose entity of the Poznań university of economics and business (the SPV of the PUEB) as an example of support for research commercialization in Poland", Studia Oeconomica Posnaniensia, Vol. 4 No. 5, doi: 10.18559/ SOEP.2016.5.7.

TACR (2014), "Motives, barriers, and services regarding technology transfer in the Czech Republic - an analysis of the TA CR survey 2014", available at: https://www.tacr.cz/dokums_raw/novinky/ 2014_tacr_motives, $\% 20$ barriers, $\% 20$ and $\% 20$ services $\% 20$ regarding $\% 20$ tt $\% 20$ in $\% 20$ the $\%$ 20cz.pdf

Ting, S.H., Yahya, S. and Tan, C.L. (2019), "The influence of researcher competence on universityindustry collaboration. The mediating role of domain knowledge transfers and spillovers", Journal of Entrepreneurship in Emerging Economies, Vol. 11 No. 2, pp. 277-303.

Trzmielak, D.M. (2013), "Komercializacja wiedzy i technologii - determinanty i strategie (commercialisation of knowledge and technology - determinants and strategies)", Wydawnictwo Uniwersytetu Lódzkiego, Lódź.

Urbano, D. and Guerrero, M. (2013), "Entrepreneurial universities: socioeconomic impacts of academic entrepreneurship in a European region", Economic Development Quarterly, Vol. 27 No. 1, pp. 40-55.

Van Norman, G.A. and Eisenkot, R. (2017), "Technology transfer: from the research bench to commercialization: part 2: the commercialization process", JACC: Basic to Translational Science, Vol. 2 No. 2, pp. 197-208.

Witt, U. and Zellner, C. (2005), "Knowledge-based entrepreneurship: the organizational side of technology commercialization", The Papers on Economics and Evolution, doi: 10.1017/CBO9780511618390.019.

Wnuk, U. and Tommei, S. (2015), "Public research-based spin-offs in Italy and Poland: similarities and differences in policies, procedures and performance", available at: http://yadda.icm. edu.pl/yadda/element/bwmeta1.element.baztech-c1a914ac-1a6e-4349-b9bb-df60c311\% 95/c/ wnuk_tommei_public_4_2015.pdf

Wright, M., Clarysse, B., Lockett, A. and Knockaert, M. (2008), "Mid-range universities' in Europe linkages with industry: knowledge types and the role of intermediaries", Research Policy, Vol. 37 No. 8, pp. 1205-1223.

Wright, M., Piva, E., Mosey, S. and Lockett, A. (2009), "Business schools and academic entrepreneurship", The Journal of Technology Transfer, Vol. 34 No. 6, pp. 560-587.

Yin, K.R. (1994), Case Study Research and Applications: Design and Methods, 2nd ed., Sage Publishing, Thousand Oaks, CA.

Yin, K.R. (2018), Case Study Research and Applications: Design and Methods, 6th ed., Sage Publishing, Thousand Oaks, CA. 


\section{Further reading}

Morris, F., Rasmussen, E., Toschi, L. and Villani, E. (2016), "Determinants of the university technology transfer policy-mix: a cross-national analysis of gap-funding instruments", The Journal of Technology Transfer, Vol. 41 No. 6, pp. 1377-1405.

Who really acts as an entrepreneur

Virtanen, M. and Laukkanen, M. (2002), "Towards HEI-based new venture generating tool: the 'business lab' of the university of Kuopio, Finland”, Industry and Higher Education, Vol. 16 No. 3, pp. 159-166.

\section{Corresponding author}

Aleksandra Szulczewska-Remi can be contacted at: Aleksandra.Szulczewska-Remi@ue.poznan.pl

For instructions on how to order reprints of this article, please visit our website: www.emeraldgrouppublishing.com/licensing/reprints.htm Or contact us for further details: permissions@emeraldinsight.com 